\title{
RIFT SYSTEMS OF THE RUSSIAN EASTERN ARCTIC SHELF AND ARCTIC DEEP WATER BASINS: LINK BETWEEN GEOLOGICAL HISTORY AND GEODYNAMICS
}

\author{
A. M. Nikishin'1, E .I. Petrov², N. A. Malyshev³, V. P. Ershova1 \\ ${ }^{1}$ M.V. Lomonosov Moscow State University, Faculty of geology, Moscow, Russia \\ 2 Federal Agency for Subsoil Use, Moscow, Russia \\ ${ }^{3}$ Rosneft, Moscow, Russia
}

\begin{abstract}
In our study, we have developed a new tectonic scheme of the Arctic Ocean, which is based mainly on seismic profiles obtained in the Arctic-2011, Arctic-2012 and Arctic-2014 Projects implemented in Russia. Having interpreted many seismic profiles, we propose a new seismic stratigraphy of the Arctic Ocean. Our main conclusions are drawn from the interpretation of the seismic profiles and the analysis of the regional geological data. The results of our study show that rift systems within the Laptev, the East Siberian and the Chukchi Seas were formed not earlier than Aptian. The geological structure of the Eurasian, Podvodnikov, Toll and Makarov Basins is described in this paper. Having synthesized all the available data on the study area, we propose the following model of the geological history of the Arctic Ocean: 1. The Canada Basin formed till the Aptian (probably, during Hauterivian-Barremian time). 2. During the Aptian-Albian, large-scale tectonic and magmatic events took place, including plume magmatism in the area of the De Long Islands, Mendeleev Ridge and other regions. Continental rifting started after the completion of the Verkhoyansk-Chukotka orogeny, and rifting occurred on the shelf of the Laptev, East Siberian, North Chukchi and South Chukchi basins, and the Chukchi Plateau; simultaneously, continental rifting started in the Podvodnikov and Toll basins. 3. Perhaps the Late Cretaceous rifting continued in the Podvodnikov and Toll basins. 4. At the end of the Late Cretaceous and Paleocene, the Makarov basin was formed by rifting, although local spreading of oceanic crust during its formation cannot be excluded. 5. The Eurasian Basin started to open in the Early Eocene. We, of course, accept that our model of the geological history of the Arctic Ocean, being preliminary and debatable, may need further refining. In this paper, we have shown a link between the continental rift systems on the shelf and the formation history of the Arctic Ocean.
\end{abstract}

Key words: Arctic; Eurasia Basin; North Chukchi Basin; Laptev Sea Basin; East Siberian Sea Basin; Podvodnikov Basin; Lomonosov Ridge; Mendeleev Ridge; Gakkel Ridge; Makarov Basin; rift; sedimentary basin; seismic line

\section{RESEARCH ARTICLE}

Received: May 30, 2016

Recommended by S.V. Rasskazov (Guest Editor)

For citation: Nikishin A.M., Petrov E.I., Malyshev N.A., Ershova V.P., 2017. Rift systems of the Russian Eastern Arctic shelf and Arctic deep water basins: link between geological history and geodynamics. Geodynamics \& Tectonophysics 8 (1), 11-43. doi:10.5800/GT-2017-8-10231. 


\title{
РИФТОВЫЕ СИСТЕМЫ ШЕЛЬФА РОССИЙСКОЙ ВОСТОЧНОЙ АРКТИКИ И АРКТИЧЕСКОГО ГЛУБОКОВОДНОГО БАССЕЙНА: СВЯЗЬ ГЕОЛОГИЧЕСКОЙ ИСТОРИИ И ГЕОДИНАМИКИ
}

\author{
А. М. Никишин', Е. И. Петров², Н. А. Малышев³, В. П. Ершова ${ }^{1}$
${ }^{1}$ Московский государственный университет им. М.В. Ломоносова, геологический факультет, Москва, Россия
3 Роснефть, Москва, Россия \\ 2 Федеральное агентство по недропользованию (РОСНЕДРА), Москва, Россия
}

\begin{abstract}
Аннотация: На основе российских сейсмических профилей, полученных в рамках проектов Арктика-2011, Арктика-2012 и Арктика-2014, составлена новая тектоническая схема Арктического океана. Приведены результаты интерпретации многих сейсмических профилей, представлена новая сейсмостратиграфия для Арктического океана. Основные выводы сделаны на основе интерпретации сейсмических профилей и на базе анализа региональных геологических данных. Показано, что рифтовые системы в пределах морей Лаптевых, Восточно-Сибирского и Чукотского были образованы не раньше аптского времени. Дано описание геологического строения бассейнов Евразийского, Подводников, Толля, Макарова и других. На основе синтеза всех данных получена следующая модель истории Арктического океана. 1. Канадский бассейн был образован до аптского времени (вероятно, в готериве-барреме). 2. В апте-альбе были крупномасштабные тектонические и магматические события: плюмовый магматизм был в районе поднятия Де-Лонга, на хребте Менделеева и в других областях. Континентальный рифтинг произошел сразу после окончания Верхоянско-Чукотской орогении и рифтинг был на шельфе морей Лаптевых, Восточно-Сибирского, Северо-Чукотского и ЮжноЧукотского и на поднятии Чукотского плато; одновременно континентальный рифтинг начался в бассейнах Подводников и Толля. 3. В позднем мелу рифтинг, возможно, продолжился в бассейнах Подводников и Толля. 4. В конце позднего мела и в палеоцене в ходе рифтинга был образован бассейн Макарова; локальный спрединг океанической коры при формировании бассейна Макарова не исключен. 5. Евразийский бассейн начал образовываться в начале эоцена. Наша модель геологической истории Арктического океана является предварительной и дискуссионной. В целом, мы показали связь континентальных рифтовых систем на шельфах с историей раскрытия Арктического океана.
\end{abstract}

Ключевые слова: Арктика; Евразийский бассейн; Северо-Чукотский бассейн; бассейн моря Лаптевых; бассейн Восточно-Сибирского моря; бассейн Подводников; хребет Ломоносова; хребет Менделеева; хребет Гаккеля; бассейн Макарова; рифт; осадочный бассейн; сейсмический профиль

\section{INTRODUCTION}

The tectonic structure of the Arctic Ocean was discussed recently in a series of reviews (Fig. 1) [e.g., Laverov et al., 2013; Vernikovsky et al., 2013; Gaina et al., 2014; Pease et al., 2014; Nikishin et al, 2014; Petrov et al., 2016; Drachev, 2016]. Different versions of the stratigraphy of the ocean's sedimentary cover were presented in [Kim, Glezer, 2007; Backman et al., 2008; Bruvoll et al., 2010, 2012; Rekant, Gusev, 2012; Mosher et al., 2012; Døssing et al., 2013; Dobretsov et al., 2013; Weigelt et al., 2014; Jokat, Ickrath, 2015; Nikishin et al., 2014; Brumley, 2014; Rekant et al., 2015; Evangelatos, Mosher, 2016]. Large-scale seismic surveys were recently conducted on the shelves of the Laptev, East Siberian and Chukchi Seas, as well as in the deep-water part of the Arctic Ocean [Nikishin et al., 2014; Rekant et al., 2015]. Rocks sampled during dredging and drilling of shallow holes on the Lomonosov and Mendeleev Ridges were studied [Morozov et al., 2013; Vernikovsky et al., 2014; Petrov et al., 2016].

Rift systems on the Laptev, East Siberian and Chukchi Shelves were described in numerous works, and reviews were presented in [Drachev et al., 2010; $\mathrm{Ni}$ kishin et al., 2014]. The present-day Gakkel oceanic rift is known in the Eurasian Basin (e.g., [Glebovsky et al., 2006, 2013; Gaina et al., 2014]). An abandoned Mesozoic (Early Cretaceous ?) oceanic rift is known along the axis of the Canada Basin [Pease et al., 2014; Chian et al., 2016]. Intraplate normal faults are known on the Lomonosov and Mendeleev Ridges [Bruvoll et al., 2010; Nikishin et al., 2014; Brumley, 2014].

In 2011, 2012 and 2014, large-scale seismic surveys were conducted by Russia in the Arctic Ocean. More than 20560 line $\mathrm{km}$ of 2D seismic lines were acquired [Nikishin et al., 2014; Rekant et al., 2015]. At the same 


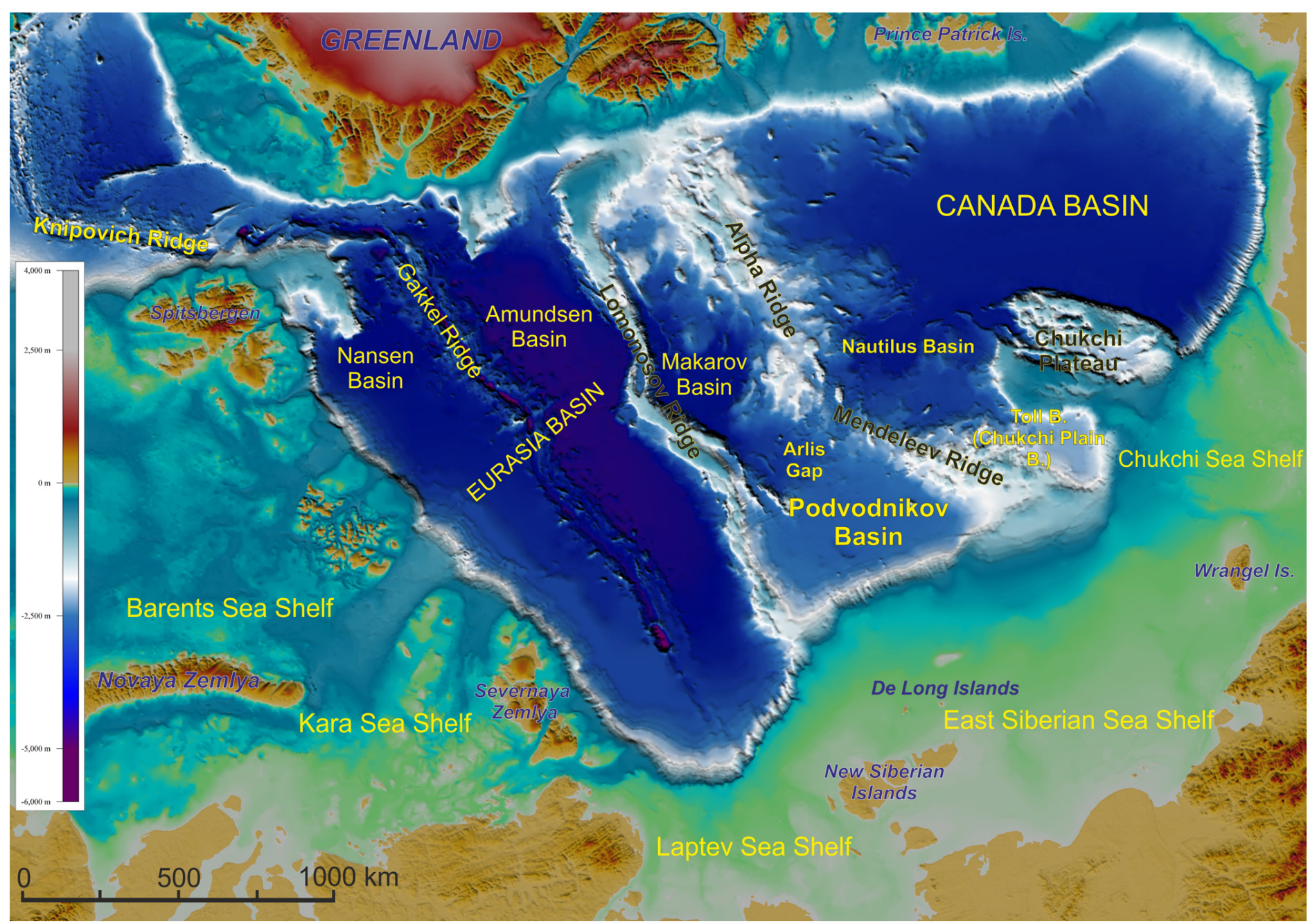

Fig. 1. Topographic map of the Arctic Ocean showing the main morphological features of the Arctic region.

Рис. 1. Топографическая карта Арктического океана и основные морфологические элементы.

time, operations of oil companies yielded new networks of seismic lines for all Russia's shelf seas. Based on these new data, we revised our concepts concerning the geology of the Arctic Ocean[Nikishin et al., 2014]. The most recent data are consolidated in the new tectonic map (Fig. 2). In this paper, we briefly characterize different continental and oceanic rift systems of the Arctic and a link between their geological history and geodynamics.

\section{STRUCTURE OF THE DEEP-WATER PART OF THE ARCTIC OCEAN}

In the structure of the Arctic Ocean deep-water part, traditionally identified are the Eurasian and Amerasian basins separated by the continental Lomonosov Ridge. The Eurasian Basin has oceanic crust. Opening of the ocean started approximately at the Paleocene and Eocene boundary (about $56 \mathrm{Ma}$ ) and continues till the present time [Glebovsky et al., 2006; Gaina et al., 2014; Pease et al., 2014; Nikishin et al., 2014].

The Amerasian Basin has a complex structure and consists of several basins and uplifts (see Fig. 1). The part of the Amerasian Basin situated farther to the south is named the Canada basin. The Alpha-Mendeleev Ridge crosses the Amerasian Basin from the shelf of Asia to the shelf of North America. The Podvodnikov Basin is situated between the Mendeleev Ridge and the Lomonosov Ridge. The Makarov Basin is located between the Alpha Ridge and the Lomonosov Ridge. The Toll Basin (or Chukchi Abyssal Plain Basin) is between the Mendeleev Ridge and the rise of the Chukchi Plateau. We suggest naming the Canada Basin as the South Amerasian domain and the remaining part of the Amerasian Basin with rises of the Alpha-Mendeleev type as the North Amerasian domain. In this paper, we do not consider the Canada Basin. New data on its structure are presented in [Mosher et al., 2012; Chian et al., 2016]. 


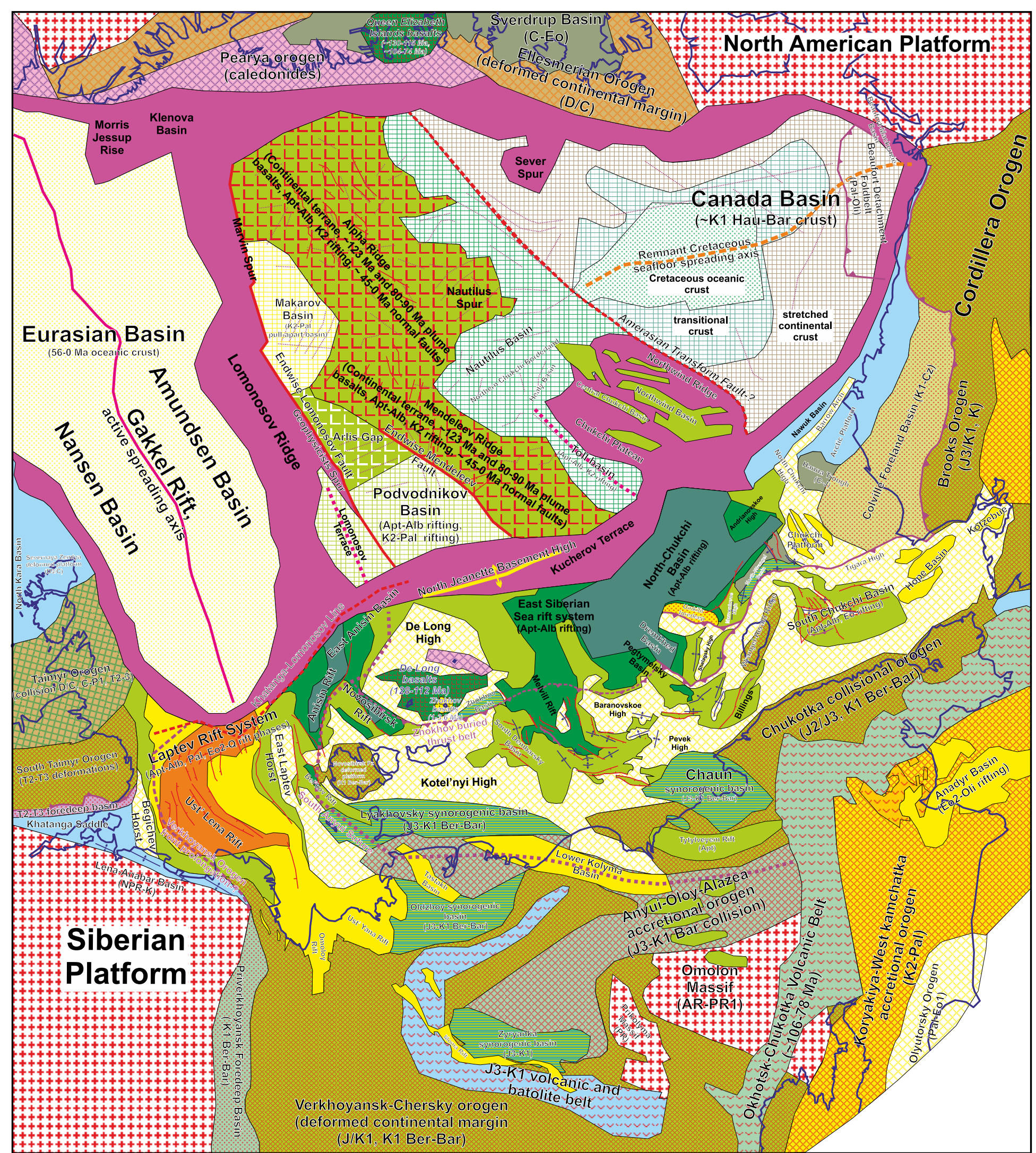

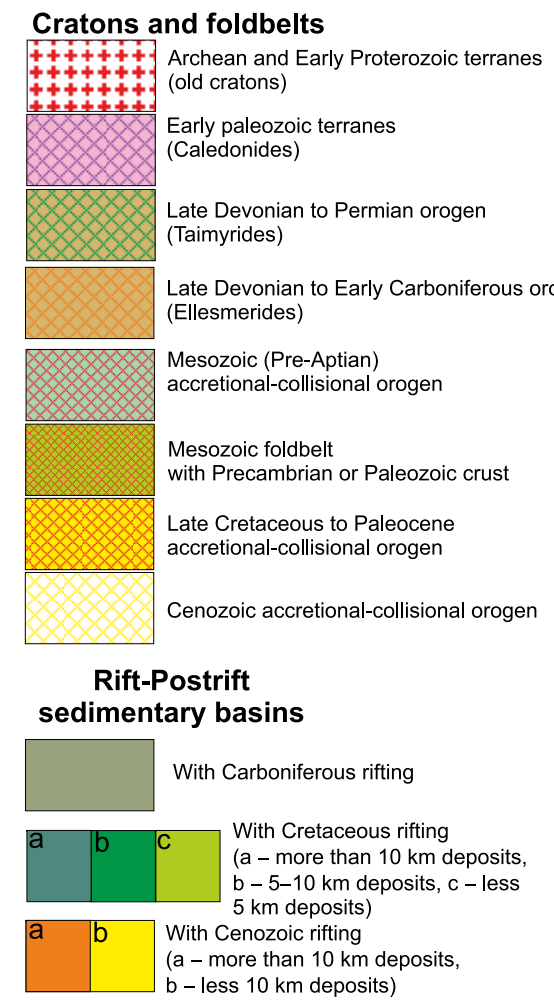

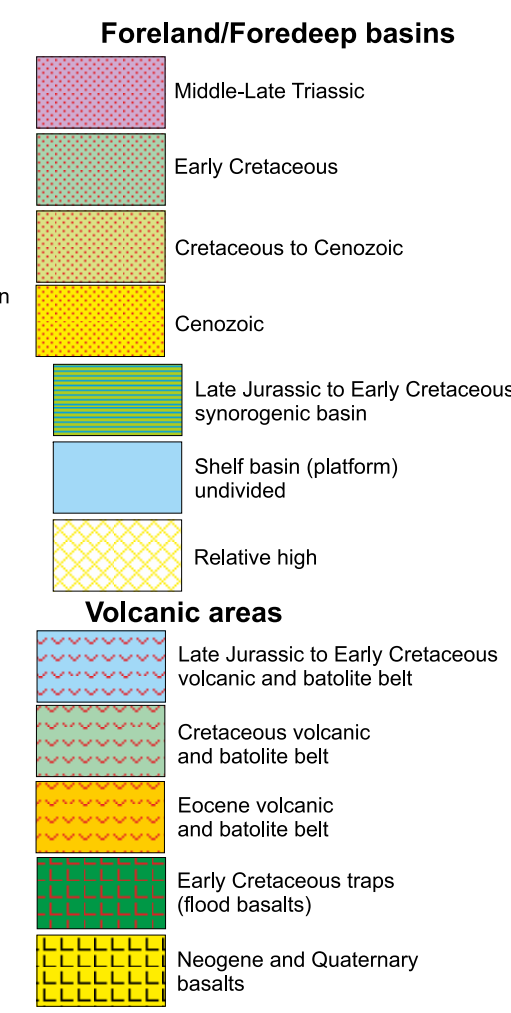

Oceanic basins, ridges, and slopes
Passive margins and
continental terraces

- $L L L L L$ Alpha-Mendeleev continental(?) terrane

ALLLLL Aris buried continental(?) terrane

Basins with oceanic or highly stretched Some structures

Normal fault

Thrust and buried thrust

1 Inversional structures

gravi-magnetic lineament
(for Apha-iendeleev Ridge
and Canada Basia area only)

$\ldots \ldots$........ axis of rititing

Fig. 2. Tectonic scheme of the Arctic Ocean region. New detailed version based on [Nikishin et al., 2014]. Data from [Mosher et al., 2012; Chian et al., 2016] are used to show Canada Basin structure.

Рис. 2. Тектоническая схема района Арктического океана. Новая версия карты, основанная на [Nikishin et al., 2014]. Структура Канадского бассейна показана с использованием данных в [Mosher et al,, 2012; Chian et al., 2016] 


\section{STRATIGRAPHY OF THE ARCTIC OCEAN}

The following data and methods are taken as the basis for considering the seismic stratigraphy of the Arctic Ocean: (1) drilling data on the Lomonosov Ridge from the ACEX Project [Moran et al., 2006; Backman et al., 2008];(2) data on ages of linear magnetic anomalies of the Eurasian Basin [Glebovsky et al., 2006; Gaina et al., 2011]; (3) data on the age of the sedimentary cover of the Chukchi Sea tied to wells [Kumar et al., 2011; Hegewald, Jokat, 2013; Nikishin et al., 2014]; data on the formation history of Mesozoic orogens in the Russian Far East and on islands of the East Siberian and Chukchi Seas; (4) data on ages of plateau basalts of the De Long Island and the Alpha-Mendeleev Ridge that are a part of the Alpha-Mendeleev LIP or HALIP [Drachev, Saunders, 2006; Grantz et al., 2011; Morozov et al., 2013; Brumley, 2014]. Earlier, we correlated the seismic stratigraphy of the Arctic Ocean with drilling data on the Lomonosov Ridge and with linear magnetic anomalies in the Eurasian Basin [Nikishin et al., 2014]. We identified seismostratigraphic boundaries with ages of about $45 \mathrm{Ma}, 34 \mathrm{Ma}$ and $20 \mathrm{Ma}$ [Nikishin et al., 2014] (Fig. 3).

In the Arctic Region, several commercial wells were drilled on the shelf in the American part of the Chukchi Sea (Popcorn, Crackerjack, Klondike, Burger, and Diamond) [Sherwood et al., 2002; Kumar et al., 2011]. Based on these data, the stratigraphic scheme was developed for the Alaska Shelf [Sherwood et al., 2002]. We compiled composite seismic profiles connecting the Russian seismic lines in the Arctic and some commercial lines on the shelf with the Popcorn-1, Crackerjack1 , and Burger-1 wells. The Cretaceous - Paleogene boundary (Mid-Brookian Unconformity, MBU) is rather reliably traced into the North Chukchi Basin and the Amerasian Basin. On the Alaska Shelf, this boundary is eroded and has an angular unconformity [Sherwood et al., 2002; Kumar et al., 2011]. In the North Chukchi Basin, the bottom of the thick lower clinoform complex corresponds to this boundary. In the Russian sector of the Chukchi Sea, there is the Wrangel-Herald Ridge [e.g. Verzhbitsky et al., 2012, 2015; Nikishin et al., 2014]. The analysis of seismic lines and AFT data shows that within the strip of this uplift, an overthrust formation phase occurred near the Cretaceous-Paleogene boundary, as well as considerable uplifting in the Maastrichtian-Paleocene [Verzhbitsky et al., 2012, 2015; Ikhsanov, 2014; Nikishin et al., 2014]. This event also extensively manifested itself on both the Alaska and the Brooks Orogen [O'Sullivan et al., 1997]. It may correspond to the start of formation of the thick clinoform complex in the North Chukchi Basin. That is why we date the bottom of the cliniform complex as the MBU boundary (66 Ma).

The most complete Cenozoic section is penetrated by the Popcorn-1 well [Sherwood et al., 2002], in which the section of the Eocene is available. The Eocene section is subdivided into three units: Lower Eocene, Middle Eocene, and Upper Eocene. The stratigraphic level with the age of about $45 \mathrm{Ma}$ in the well can be traced on seismic lines into the North Chukchi Basin and the deep-water part of the Arctic Ocean. In the North Chukchi Basin, this stratigraphic level corresponds to the bottom of the upper thick clinoform complex. This boundary is clearly traceable all over the Arctic Ocean. The Paleocene - Eocene boundary (about $56 \mathrm{Ma}$ ) is also penetrated by the Popcorn- 1 well. We traced out this boundary on seismic lines into the Arctic Ocean. The Popcorn-1 well penetrated Mesozoic deposits, though a correlation of these deposits with seismic lines in the Arctic Ocean has not unambiguously established yet because different versions of their development are possible.

In the north of the New Siberian Islands in the East Siberian Sea, there are the De Long Islands. On the Bennett Island, well-known Early Cretaceous plateau basalts overlie the Lower Paleozoic folded complex [Kos'ko et al., 2013]. The age of the basalts is about 105-128 Ma [Drachev, Saunders, 2006; Kos'ko, Trufanov, 2002; Kos'ko et al., 2013]. The basalts are underlain by Early Cretaceous sandstones with coals [Kos'ko et al., 2013]. A magnetic anomaly corresponds to the De Long Islands, which may suggest the wide development of the Early Cretaceous basalt plateau [Drachev, Saunders, 2006; Drachev et al., 2010; Gaina et al., 2011; Saltus et al., 2011; Nikishin et al., 2014]. The De Long Plateau forms an uplift that was crossed by several seismic lines. Several grabens exist around the plateau [Drachev et al., 2010; Nikishin et al., 2014]. At the base of the sedimentary cover of some grabens, packages with bright reflectors are observed. In our opinion, these bright reflectors correspond to the Le Long basalt complex with horizons of sedimentary rock [Nikishin et al., 2014]. Under this hypothesis, rifting in the East Siberian Sea started just after the end of the basalt volcanism, i.e. not earlier than the Aptian [Nikishin et al., 2014]. The age of the De Long Plateau basalts probably coincides with the age of the basalt plume magmatism on the Franz Joseph Land in the north of the Barents Sea, about 123-125 Ma [Corfu et al., 2013; Dobretsov et al., 2013].

On the Mendeleev Ridge at the slope of the Trukshin Seamount, basalts were discovered by drilling. The $\mathrm{U}-\mathrm{Pb}$ age of $127 \mathrm{Ma}$ was determined for the basalts on zircons [Morozov et al., 2013]. On the seismic line crossing the Trukshin Seamount, these basalts are included in the acoustic basement. North of the Chukchi Plateau, basalts were dredged on slopes of uplifts. It is supposed that on the Mendeleev Ridge they either are included in the acoustic basement or form high amplitude reflection [Brumley, 2014]. Their isotopic ages are 82-100 Ma and 112-124 Ma, according to [Andronikov 


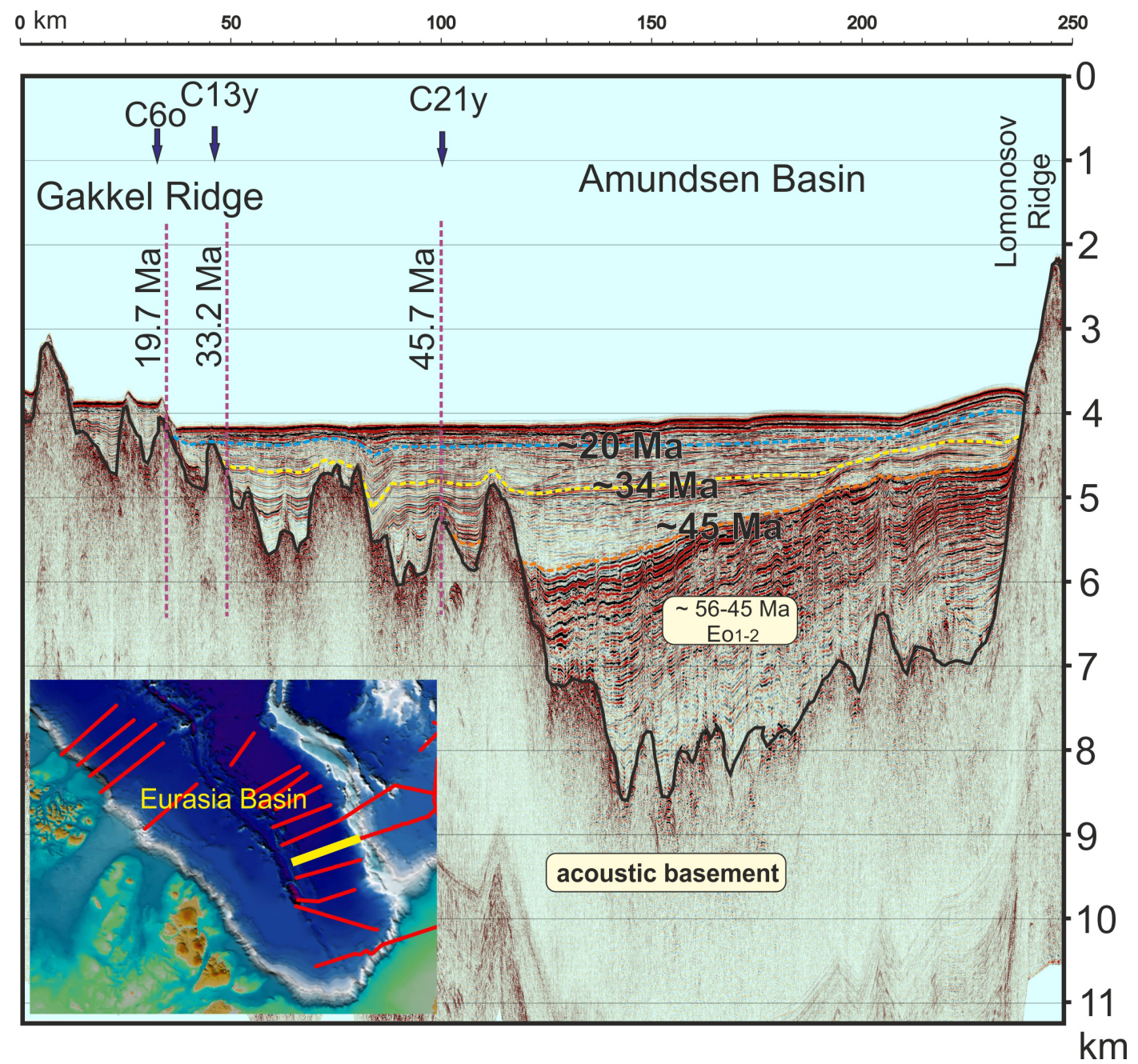

Fig. 3. Interpretation of seismic line ARC_028. Locations of linear magnetic anomalies and their ages are shown. These data are used for stratification of the Eurasia Basin. Magnetic anomalies are after [Glebovsky et al., 2006; Gaina et al., 2011]. Modified after [Nikishin et al., 2014].

Рис. 3. Интерпретация сейсмического профиля ARC_028. Показано положение линейных магнитных аномалий и их возраста. Эти данные использованы для стратификации Евразийского бассейна. Магнитные аномалии по [Glebovsky et al., 2006; Gaina et al., 2011]. Модифицировано по [Nikishin et al., 2014].

et al., 2008; Brumley, 2014]. These basalts are overlain by the sedimentary cover of the Alpha-Mendeleev Ridge. It should be noted that data on ages of volcanic rocks from the Alpha-Mendeleev Ridge are still too scarce to make adequate conclusions. It can be supposed that the sedimentary cover originates from the Middle-Upper Cretaceous.

Within the shelves of the East Siberian and Chukchi Seas, a large system of continental rifts exists [Drachev et al., 2010; Nikishin et al., 2014]. It is most likely that rifting started in the Aptian. For these rifts, the rift/postrift boundary is identified on seismic lines. Its accurate dating is difficult. Since an unconformity exists between the Albian and the Cenomanian, we suggest a hypothesis that this boundary corresponds to the rift/postrift boundary, and we conventionally date it as $100 \mathrm{Ma}$.
It is supposed that in the course of formation of the Eurasian Basin, movements of the Lomonosov Ridge from the Barents-Kara Shelf took place. The breakuptype unconformity on the shelves with the age of about $56 \mathrm{Ma}$ corresponds to the start of spreading [Drachev et al., 2010; Franke, 2013; Weigelt et al., 2014; Nikishin et al., 2014]. This boundary is traced on the slopes of the Lomonosov Ridge and can be tied up with boundaries of seismic sequences in the Arctic Ocean [Nikishin et al., 2014].

Thus, we can identify the following seismic stratigraphic boundaries in the Arctic Ocean: 125 Ma (volcanism on the De Long Plateau and on the Franz Joseph Land and the start of rifting in the East Siberian Sea and in the Laptev Sea); $100 \mathrm{Ma}$ (an approximate time of the rift/postrift boundary in the Laptev Sea and the East Siberian Sea); 66 Ma (the bottom of the lower clino- 
forms in the North Chukchi Basin, the boundary is traced to the wells on the Alaska Shelf; this boundary coincides nearly with uplift and erosional event in Alaska ( $\sim 60 \pm 4 \mathrm{Ma}$ ) [O'Sullivan et al., 1997]; $56 \mathrm{Ma}$ (the break-up boundary at the time of start of opening of the Eurasian Basin, the boundary is traced to the wells on the Alaska Shelf); $45 \mathrm{Ma}, 34 \mathrm{Ma}$, and $20 \mathrm{Ma}$. The three latter boundaries were identified through correlations of the seismic stratigraphy and linear magnetic anomalies in the Eurasian basin. They have been traced to the wells on the Alaska Shelf. These boundaries closely match the timing of uplifting and erosion events in Alaska: $\sim 46 \pm 3 \mathrm{Ma}, \sim 35 \pm 2 \mathrm{Ma}$, and $\sim 24 \pm 3 \mathrm{Ma}$, according to [O'Sullivan et al., 1997].

It must be admitted that the model of the stratigraphy is still preliminary and needs refining. However, currently, in the absence of wells, we cannot unambiguously determine the ages of seismostratigraphic complexes.

\section{DATA ON FORMATION HISTORY OF MESOZOIC OROGENS ON THE ISLANDS OF THE EAST SIBERIAN AND CHUKCHI SEAS}

In the Russia's Far East, the Verkhoyansk-Chukotka orogen of the Mesozoic age occupies the area from the Verkhoyansk Range to the Chukchi Peninsula. The main collisions were in the Early Cretaceous, and the postcollisional tension and intrusion of granites took place about 118-110 Ma [Parfenov, Kuzmin, 2001; Sokolov et al., 2002; Miller et al., 2008, 2010; Kuzmichev, 2009]. A similar history was documented for Alaska [Miller, Hudson, 1991].

Mesozoic folding deformations were widely manifested on the New Siberian Islands in the East Siberian Sea and on the Wrangel Island in the Chukchi Sea. On the New Siberian Islands, the collisional orogeny ended before the Mid Aptian. Upper Aptian deposits overlie the Paleozoic-Lower Jurassic folded complex with an angular unconformity [Kos'ko, Trufanov, 2002; Kos'ko et al., 2013; Kuzmichev et al., 2009, 2013]. The following sedimentary sequences are identified on these islands [Kos'ko et al., 2013; Kuzmichev et al., 2009, 2013]: Late Aptian - Albian, Upper Cretaceous, Upper Paleocene Eocene, Upper Oligocene - Lower Miocene, Upper Miocene - Quaternary. Sedimentation hiatuses are revealed at the Albian/Cenomanian boundary, in the Early Paleocene, at the Eocene/Oligocene boundary, and in the Middle Miocene. All the deposits are represented mainly by continental sandstones, siltstones, and clays with coal horizons. Shallow-marine sediments are detected in Eocene. The presence of the Mesozoic preAptian orogeny on the New Siberian Islands and significant pre-Aptian erosion gives evidence that sedimentary complexes of the rift system of the East Siberian
Sea located nearby are not older than the Aptian [Nikishin et al., 2014]. The sedimentary cover of the East Siberian Sea system of rifts is traced on seismic lines into the Podvodnikov Basin of the Arctic Ocean.

On the Wrangel Island, Silurian-Triassic deposits form a folded structure with cleavage [Kos'ko et al., 1993; Verzhbitsky et al., 2015]. It is believed that the main folding took place in the Late Jurassic - Early Cretaceous about 150-120 Ma, and a significant uplifting phase was about 70-64 Ma [Miller, Hudson, 1991; Kos'ko et al., 1993; Miller et al., 2010; Verzhbitsky et al., 2012, 2015; Ikhsanov, 2014; Moore et al., 2015]. The North Chukchi Basin is situated north of the Wrangel Island. The seismic lines show that the sedimentary cover of the North Chukchi Basin probably overlies a fold structure found on the Wrangel Island [Nikishin et al., 2014]. Hence, the formation time of the North Chukchi Basin is not older then the Aptian [Nikishin et al., 2014; Ikhsanov, 2014].

\section{INTERPRETATION OF REGIONAL SEISMIC PROFILES}

For the Arctic Region, we created a series of superregional composite seismic profiles that tie up the deep-water and shelf basins. For the deep-water part, Russian seismic lines acquired in the course of the government-funded Arctic-2011, Arctic-2012, and Arctic2014 Projects are utilized. For the shelf part, we used some commercial seismic lines. The profiles used to trace the identified seismic boundaries are shown in Figures 4 to 22 .

\section{RIFT SYSTEMS IN SHELF AREAS OF THE LAPTEV, EAST SIBERIAN AND CHUKCHI SEAS}

Within the shelf areas of the Laptev, East Siberian and Chukchi Seas, numerous rifts were identified (see Fig. 2) [Drachev et al., 2010; Nikishin et al., 2014]. The main issue is correctly determining the age of rifting in different rift systems.

For the area of the De Long Islands, we have shown that bright reflector packages at the base of some rifts may correspond to the Early Cretaceous (probably Early Aptian) basalts of the De Long Plateau. In the area of the Zhokhov Island, an angular unconformity is also seen at the base of synrift deposits [Nikishin et al., 2014]. We suppose that this unconformity just corresponds to the Pre-Aptian (Intra-Aptian - ?) unconformity on the New Siberian Islands; over there, coal-bearing Aptian deposits overlie folded complexes of Paleozoic to Lower Jurassic age. These data allow us to make an assumption that rifting in the Laptev Sea and the East Siberia Sea started in the Aptian, i.e. right after the completion of the Verkhoyansk-Chukotka collision. The 


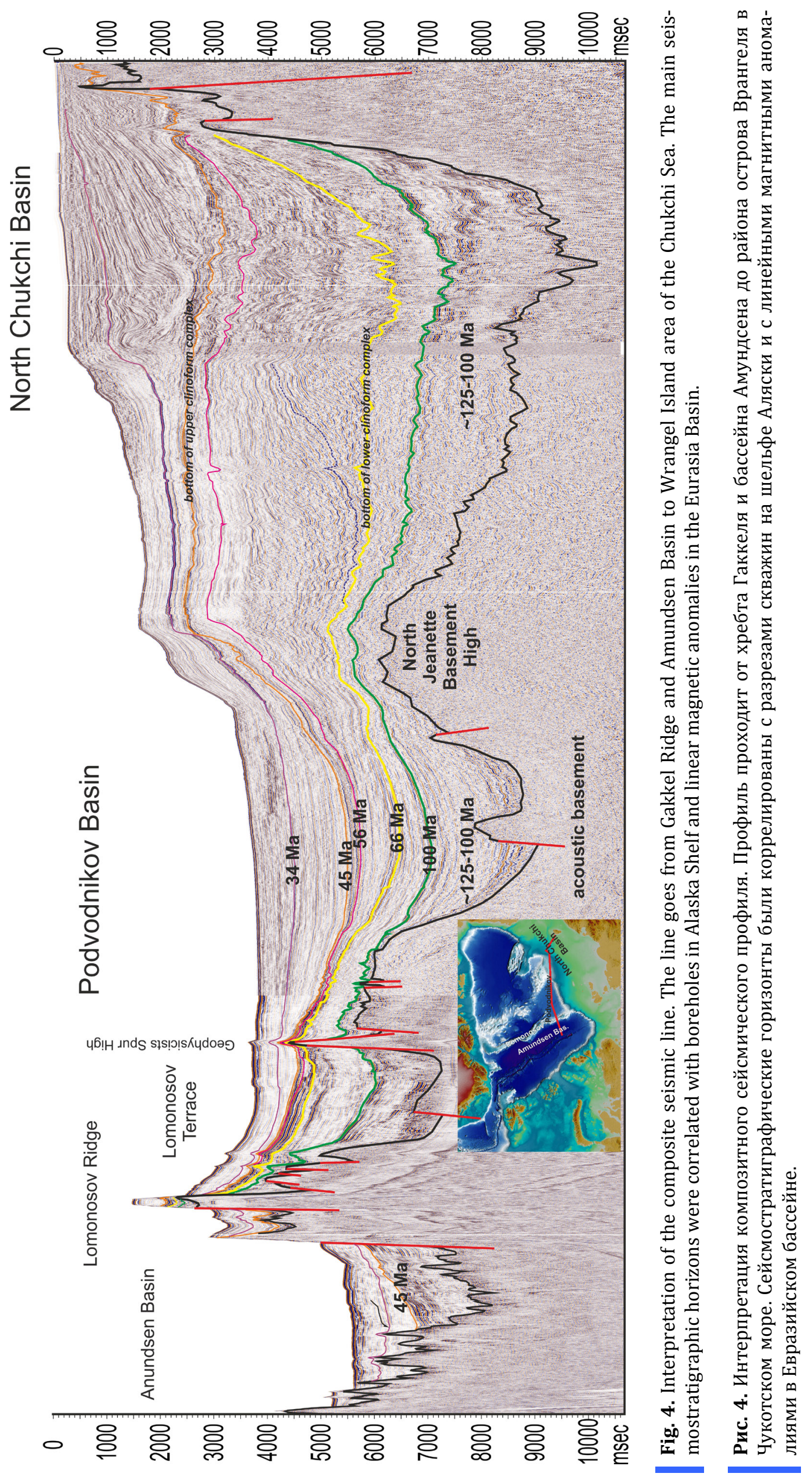



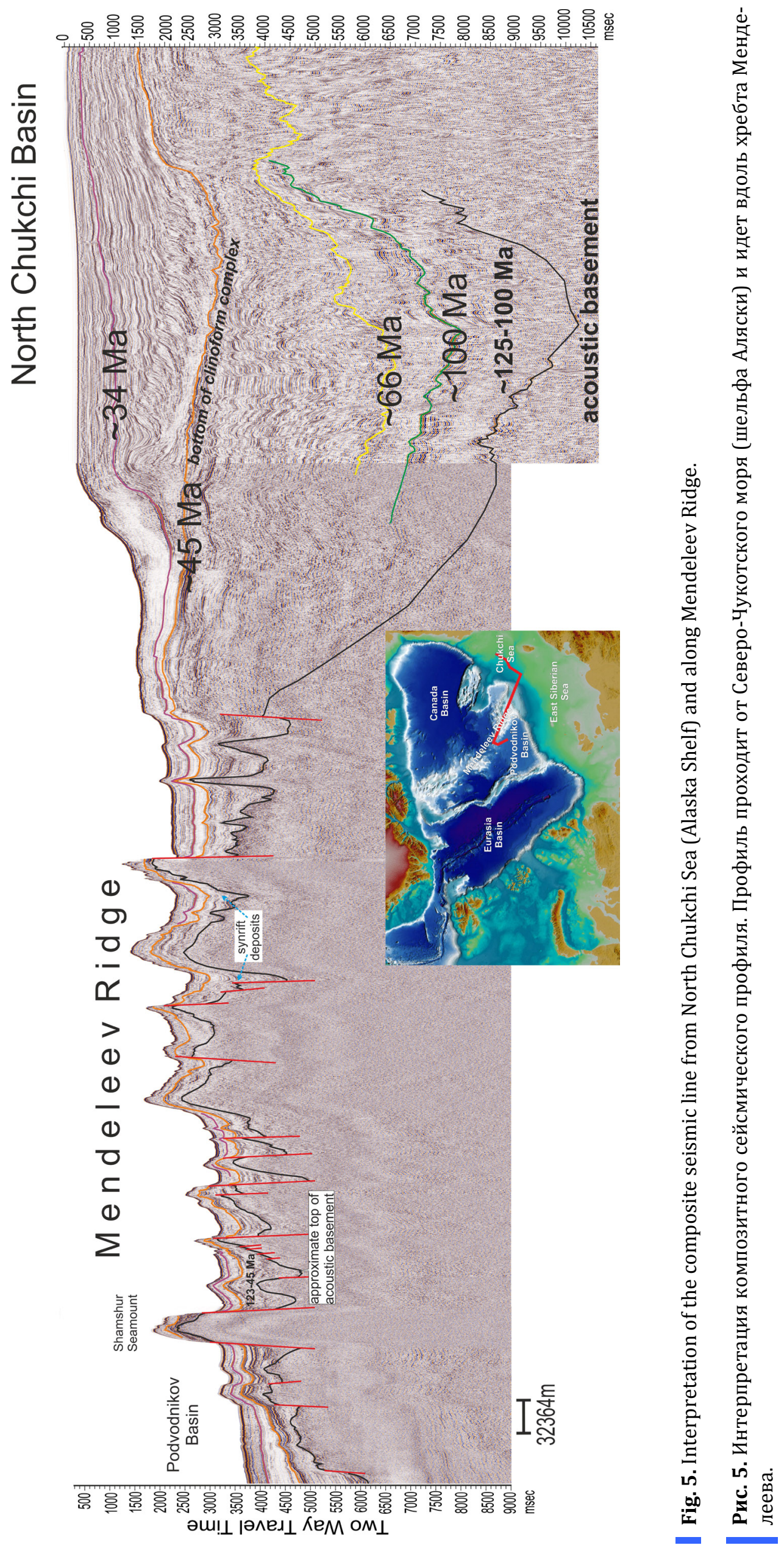

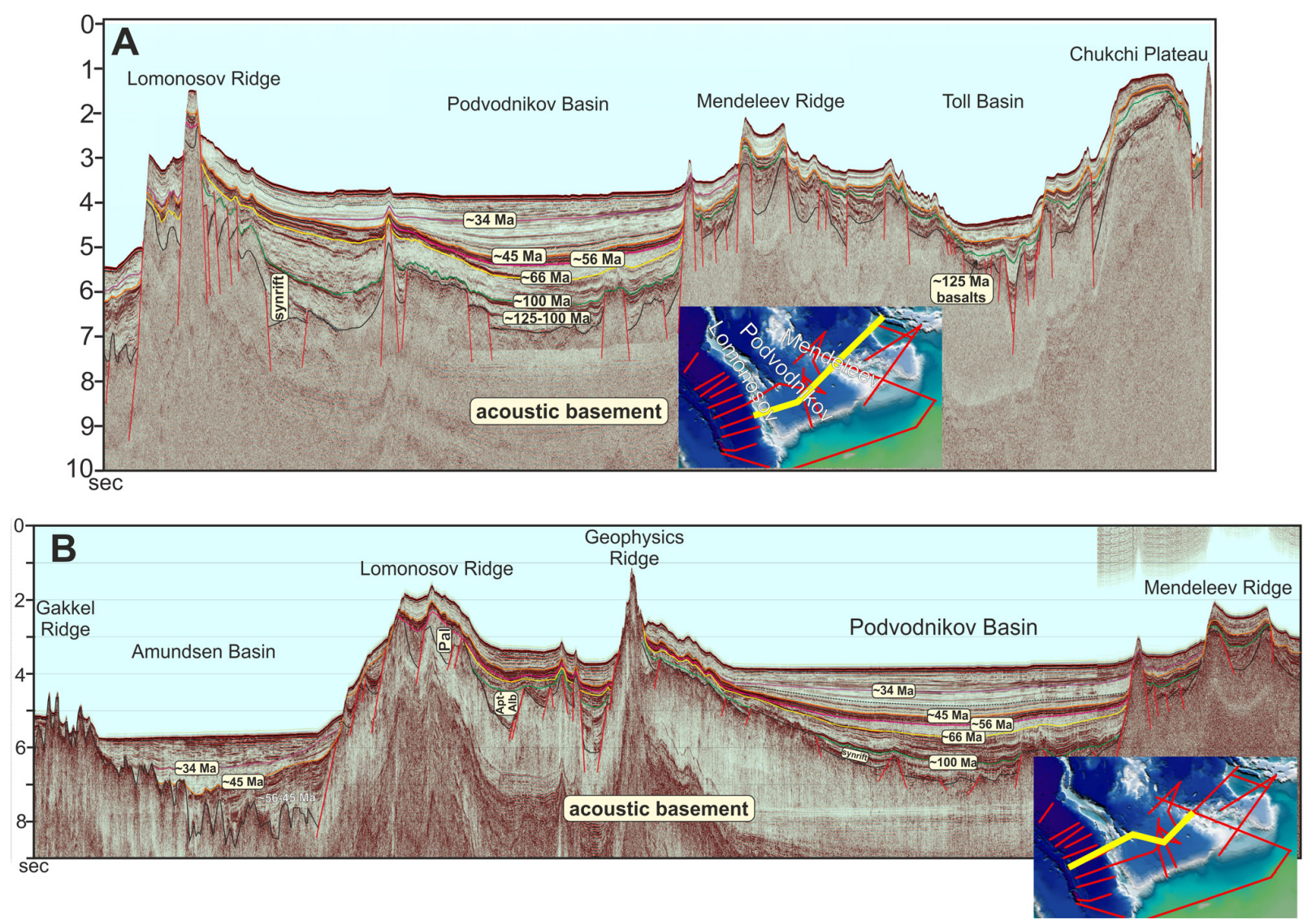

Fig. 6. Interpretation of the composite seismic lines $(A$ and $B)$ across area from Amundsen Basin toward Mendeleev Ridge and Chukchi Plateau. Modified after [Nikishin et al., 2014].

Рис. 6. Интерпретации композитных сейсмических профилей ( $A$ и $B$ ) через районы от бассейна Амундсена до хребта Менделеева и Чукотского плато. Модифицировано по [Nikishin et al., 2014].

start of rifting can be considered as a collapse of the collisional orogen [Miller, Verzhbitsky, 2009; Nikishin et al., 2014]. Similar data on ages of the rifts in the Laptev and the East Siberian seas were presented in [Zavarzina, Shkarubo, 2012; Khoroshilova et al., 2014; Petrovskaya, Savishkina, 2014]. A similar concept was suggested in [Sekretov, 2001] on the basis of the first seismic lines in the region. The correlation of seismic lines for the East Siberian and Chukchi Seas suggests a high probability that rifting started simultaneously in the North Chukchi and the South Chukchi rift systems [Nikishin et al., 2014]. This timeline is also confirmed by the interpretation of the new network of seismic lines (see Figs. 4, 5, 7, 8, 9, 10, 17, 21, and 22).

The thickness of sediments reaches $20 \mathrm{~km}$ in the North Chukchi basin, probably exceeds $15 \mathrm{~km}$ in the north of the East Siberian Sea, and amounts to $15 \mathrm{~km}$. in the Ust' Lena rift of the Laptev Sea basin.

This means that all these rifts belong to the category of super-deep basins (see Figs. 4, 5, 7, 8, 9, and 17). The bottoms of the super-deep parts of these basins are flattened on the seismic lines, which may be indicative of a hyper-extended continental crust.
In the Laptev Sea Basin, the rift phase is detected in the Paleocene, which preceded the opening of the Eurasian Basin about 56 Ma [Khoroshilova et al., 2014; Nikishin et al., 2014]. Besides, by normal faulting occurred in the Laptev Sea Basin from the Mid Eocene till the Recent time. This process widely manifested at the continuation of the Gakkel Oceanic Ridge [Drachev et al., 2010; Nikishin et al., 2014].

In the North Chukchi Basin, two large clinoform complexes are identified on seismic lines. The lower complex has the bottom at about $66 \mathrm{Ma}$, and the upper one at about $45 \mathrm{Ma}$ (see Figs. 4, 5, 7, 8, and 9). In the oceanward direction, the complexes transit into complexes of deep-water turbidites (see Fig. 10), as evidenced by the seismic data. These clinoform complexes correspond to two orogeny phases onshore.

\section{STRUCTURE OF THE EURASIAN DEEP-WATER BASIN}

In the Eurasian Basin, four stratigraphic units can be identified with the approximate ages of 56-45 Ma (Early-Middle Eocene), 45-34 Ma (Middle Eocene - 


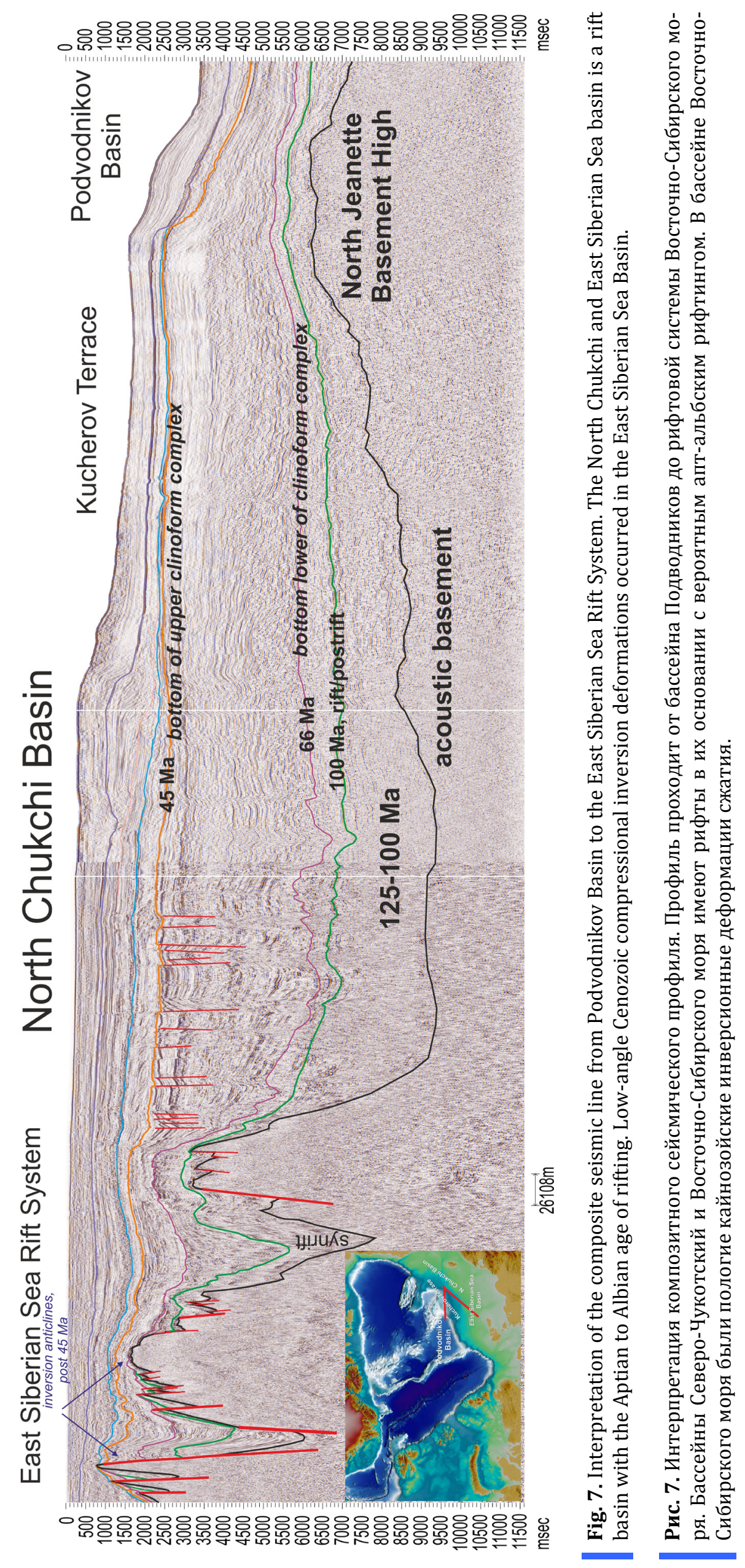




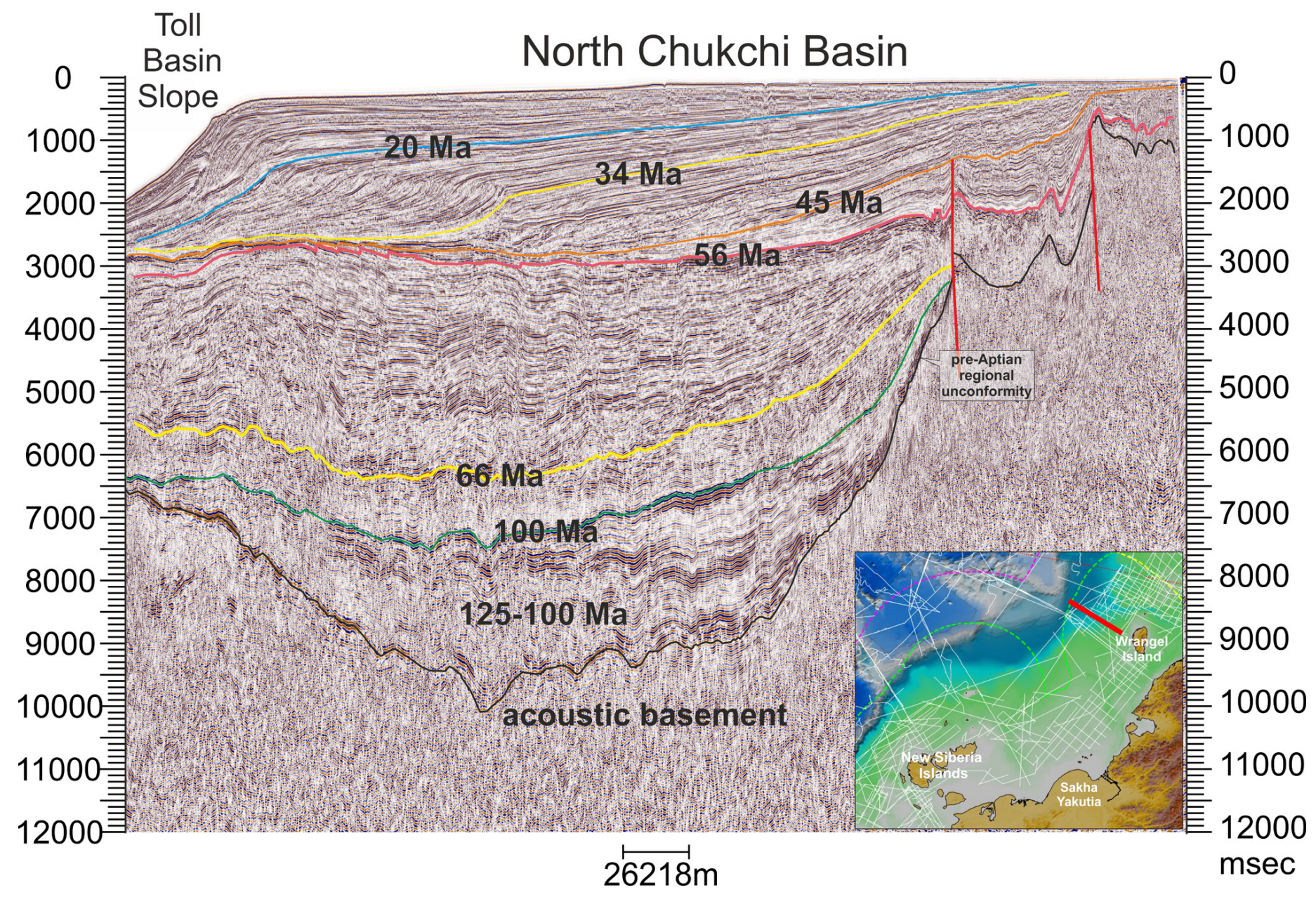

Fig. 8. Interpretation of the regional seismic line from Wrangel Island to Toll Basin.

The North Chukchi Basin gradually transforms to the Toll Basin. A possible pre-Aptian unconformity is well recognized. The North Chukchi Basin has flattened basement topography, and a highly extended continental crust is assummed. Modified after [Nikishin et al., 2014].

Рис. 8. Интерпретация регионального сейсмического профиля от района острова Врангеля и до бассейна Толля.

Северо-Чукотский бассейн плавно переходит в бассейн Толля. Видно вероятное пред-аптское несогласие. Северо-Чукотский бассейн имеет пологую топографию поверхности фундамента; вероятно, фундамент образован сильно растянутой континентальной корой. Модифицировано по [Nikishin et al., 2014].

Oligocene), 34-20 Ma, and 20-0 Ma (see Fig. 3). The basin is characteristic of a considerable asymmetry in the structure of the sedimentary cover. The Nansen Basin has a significantly thicker cover as compared to the Amundsen Basin [Nikishin et al., 2014]. This asymmetry is caused by the abnormally thick NeogeneQuaternary megasequence in the Nansen Basin.

The Gakkel Ridge is expressed in the relief of the acoustic basement as a series of sub-parallel ridges and troughs. The Russian seismic data from Arctic-2011, Arctic-2012 and Arctic-2014 Projects show a ridgetrough topography across the entire basement of the Eurasian Basin. It is thus revealed that the Early Eocene (56-45 Ma) basement has a more smoothed relief, the Middle-Late Eocene (45-34 Ma) basement has a largeramplitude relief, while the Oligocene-Quaternary base- ment relief of the oceanic crust has an abnormally dissected relief with height variations up to 1.0-1.5 sec.

The morphology of the basement of oceanic crust depending on spreading rate in different oceans is analyzed in [Elhers, Jokat, 2009]. The main conclusion of this work is that the more dissected is the oceanic crust basement top, the lower the spreading rate was. This empiric conclusion confirms that an ultra-slow spreading is taking place in the Gakkel Ridge during the latest approximately 45 million years. The ultra-slow spreading may be accompanied by formation of a special type of crust [Elkins et al., 2014; Dick et al., 2003]: rather than melting out basalts from the mantle, the mantle matter is outputted to the surface (which is termed 'exhumation of the mantle') during spreading of plates and then serpentinizes, while basalts may be melted 
Toll Basin

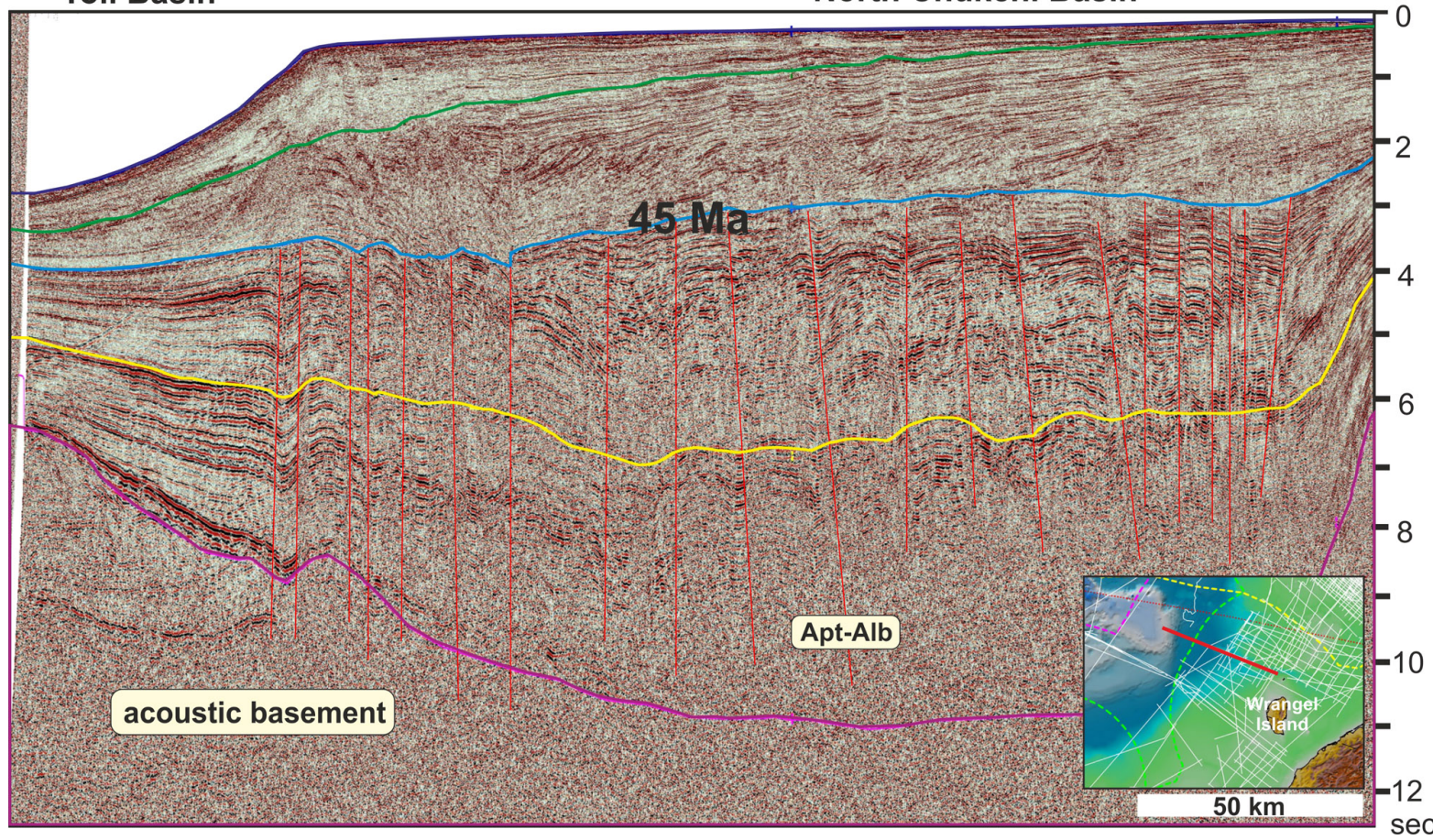

Fig. 9. Interpretation of the regional seismic line from Wrangel Island to the Toll Basin.

The profile is parallel to the previous one (Fig. 8). The thickness of the sedimentary cover in the North Chukchi Basin is up to 11 seconds. Modified after [Nikishin et al., 2014].

Рис. 9. Интерпретация регионального сейсмического профиля от района острова Врангеля и до бассейна Толля.

Профиль параллелен предыдущему профилю (см. рис. 8). Толщина осадочного чехла Северо-Чукотского бассейна достигает 11 секунд. Модифицировано по [Nikishin et al., 2014].

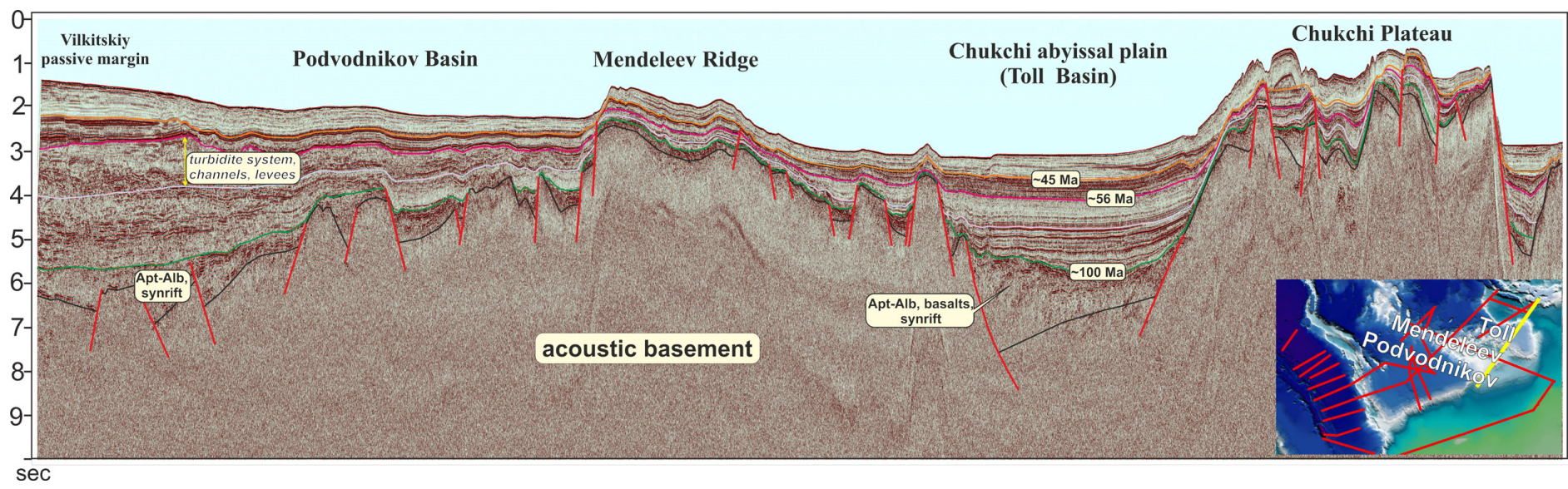

Fig. 10. Interpretation of seismic line 2012_03 going parallel to the shelf edge.

There are several graben-like structures in the lower part of the Podvodnikov Basin, which suggest large-scale continental rifting. The turbidite system is revealed below the Eocene bottom. It means that the Podvodnikov Basin was a deep-water basin in the Paleocene time at least. The synrift complex located at the bottom of the Toll Basin has reflectors that dip toward the Mendeleev Ridge. Such reflectors may represent synrift basalt volcanics. Modified after [Nikishin et al., 2014].

Рис. 10. Интерпретация сейсмического профиля 2012_03. Профиль проходит параллельно шельфу.

В нижней части бассейна Подводников выделяется много грабеноподобных структур. Это означает, что имел место значительный континентальный рифтинг. Турбидитовая система видна ниже подошвы эоцена. Из этого следует, что, по крайней мере, уже в палеоцене бассейн Подводников был глубоководным бассейном. Синрифтовый комплекс виден в основании бассейна Толля. В этом комплексе наблюдаются рефлекторы, наклоненные в сторону хребта Менделеева. Такие рефлекторы могут быть базальтовым вулканическим комплексом. Модифицировано по [Nikishin et al., 2014]. 


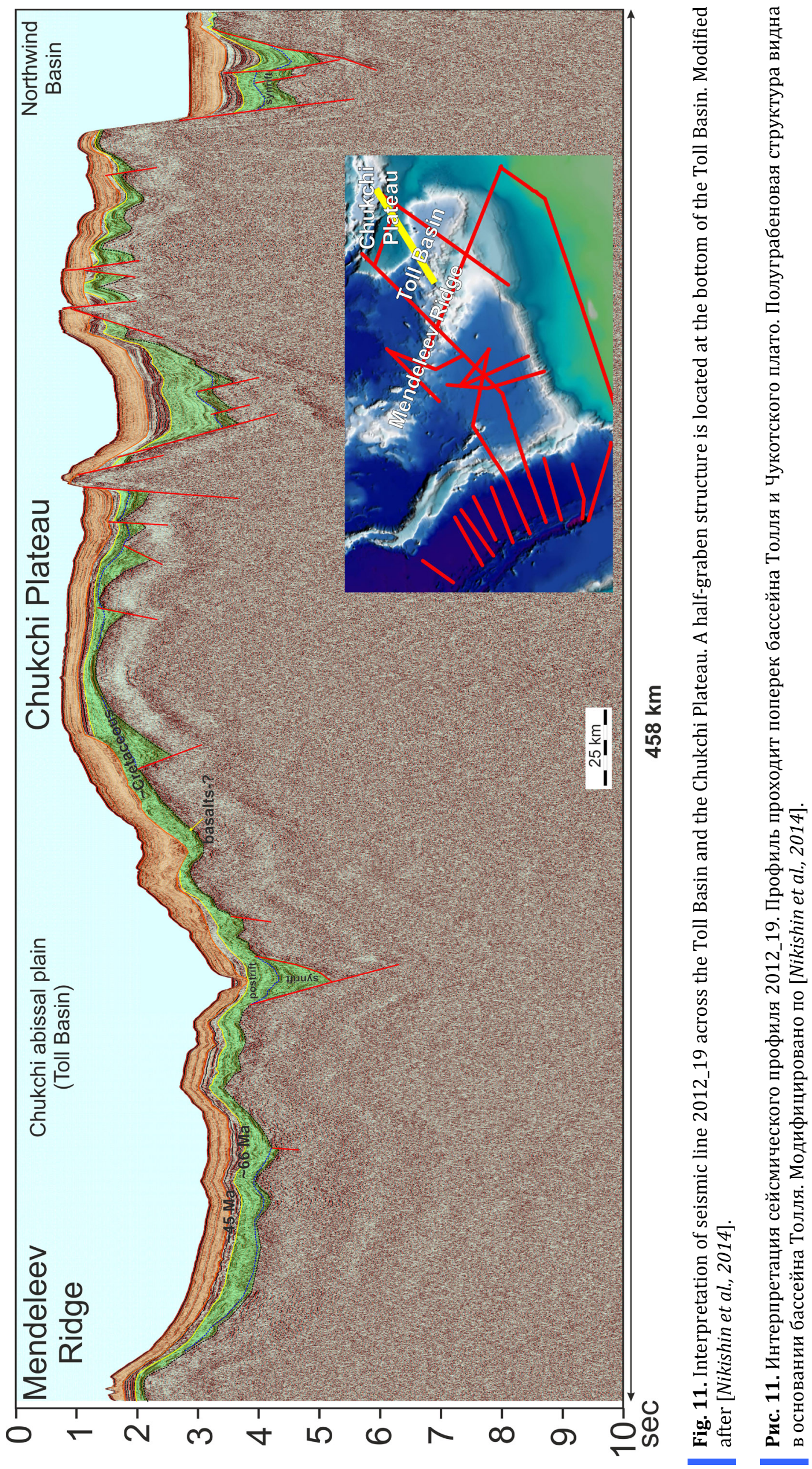


A.M. Nikishin et al.: Rift systems of the Russian Eastern Arctic shelf...

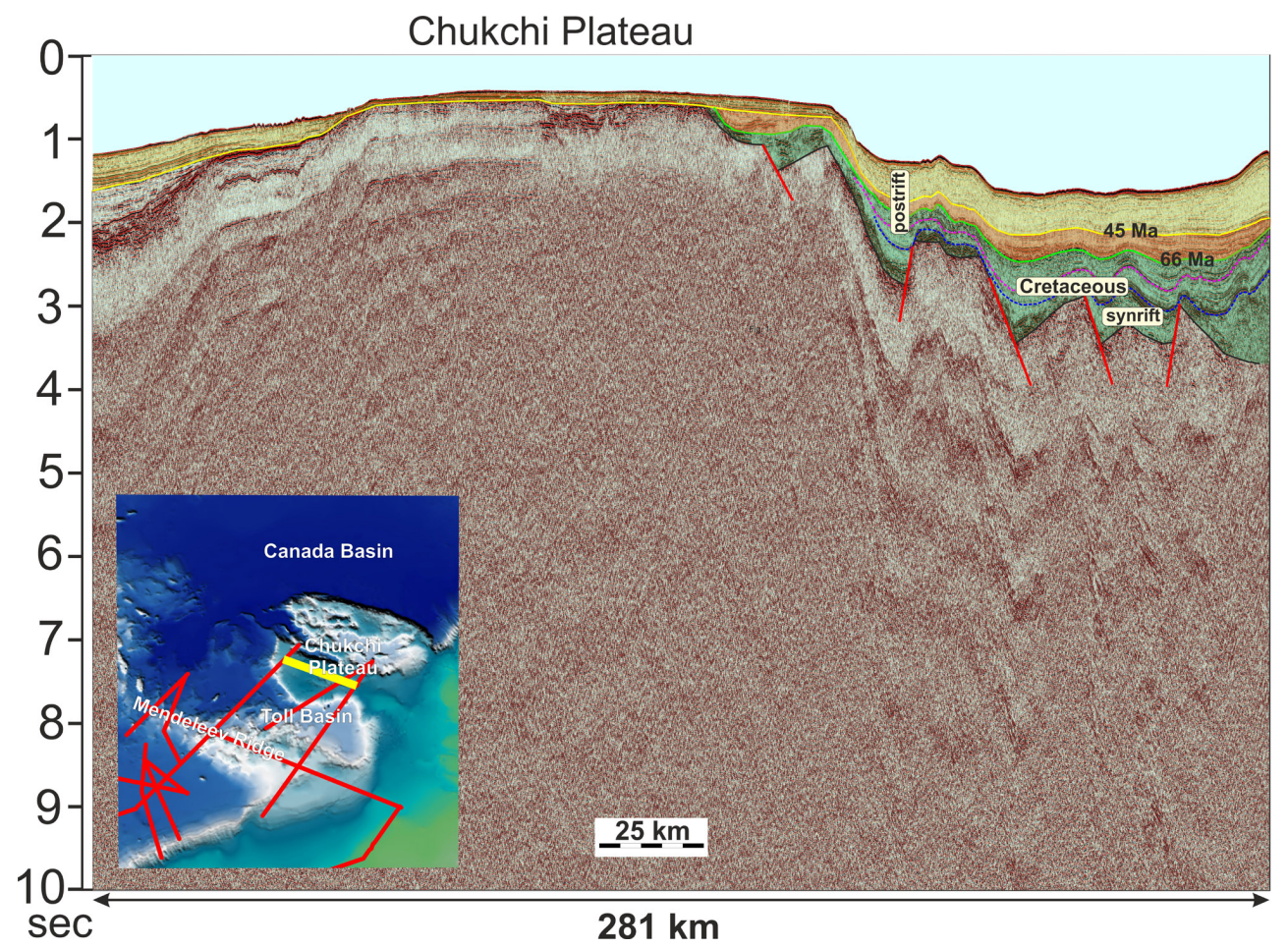

Fig. 12. Interpretation of seismic line 2012_18. The Cretaceous rift system is well recognized. Low-angle folds are revealed above the rift complex, which suggests that compression tectonics took place in the Cenozoic time. Modified after [Nikishin et al., 2014].

Рис. 12. Интерпретация сейсмического профиля 2012_18. Можно различить меловую рифтовую систему. Пологие складки наблюдаются выше рифтового комплекса. Из этого следует, что деформации сжатия были в кайнозое. Модифицировано по [Nikishin et al., 2014].

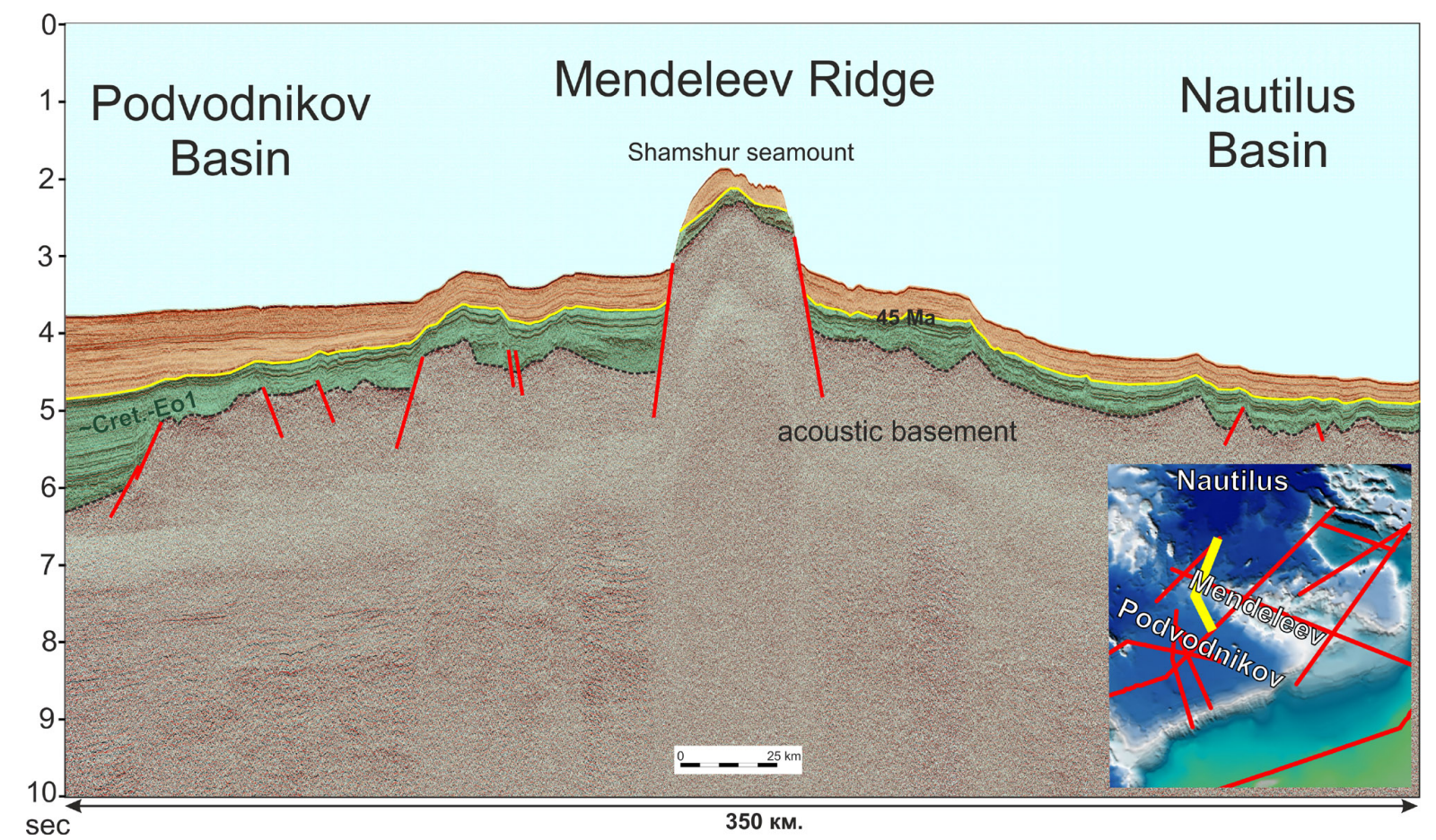

Fig. 13. Interpretation of seismic line 2012_17 across Mendeleev Ridge. Horst-like uplifts are typical for the Mendeleev Ridge. Modified after [Nikishin et al., 2014].

Рис. 13. Интерпретация сейсмического профиля 2012_17. Профиль проходит поперек хребта Менделеева. Горстоподобные поднятия типичны для хребта Менделеева. Модифицировано по [Nikishin et al., 2014]. 


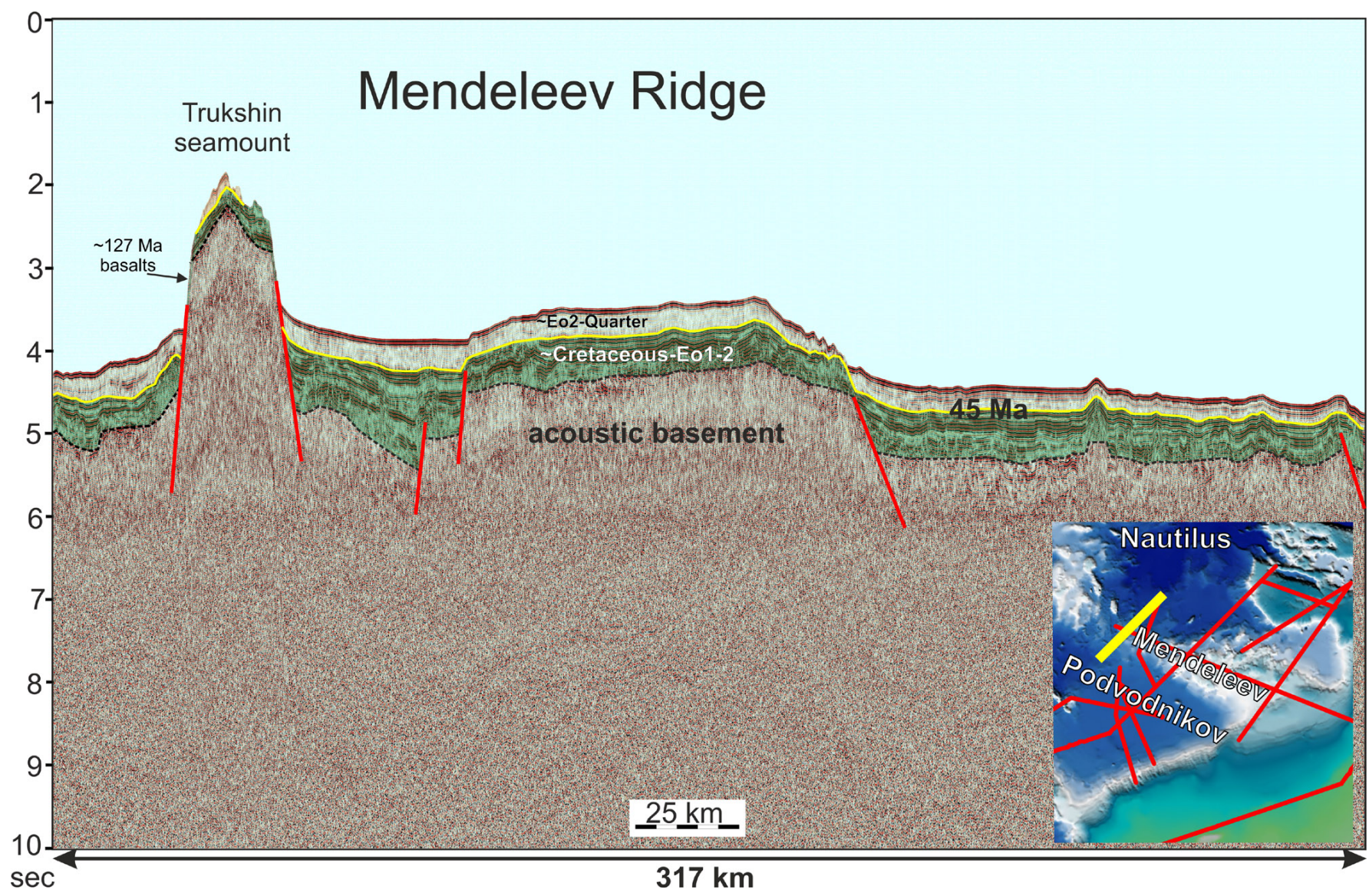

Fig. 14. Interpretation of seismic line 2012_05 across Mendeleev Ridge. Modified after [Nikishin et al., 2014].

Рис. 14. Интерпретация сейсмического профиля 2012_05. Профиль проходит поперек хребта Менделеева. Модифицировано по [Nikishin et al., 2014].

out to a small degree in a combination with exhumation of the mantle matter. The manifestations of recent volcanism along the rift valley of the Gakkel Ridge are described in [Michael et al., 2003; Cochran, 2008; Elkins et al., 2014; Schmidt-Aursch, Jokat, 2016].

\section{GEOLOGICAL STRUCTURE OF THE LOMONOSOV RIDGE}

The Lomonosov Ridge, as noted above, is a terrane with a continental crust. Our description of the cover is based mainly on the interpretation of the Russian seismic lines (see Figs. 4, 6, 15, and 16). On all of these lines, systems of half-grabens are seen at the base of the sedimentary cover, both on the Lomonosov Ridge itself and in the basin between the Lomonosov Ridge and the Geophysicists Spur. The trend of these halfgrabens coincides with the general trend of the Lomonosov Ridge. Our seismostratigraphic correlations show that the systems of grabens from the side of the Podvodnikov Basin are filled with Cretaceous deposits. Some half-grabens could have been reactivated in the Paleocene. The entire basin between the Lomonosov
Ridge and the Geophysicists Spur is probably underlain by a system of half-grabens and definitely has a continental crust. This basin and its southern continuation is a terrace of the Lomonosov Ridge, which we refer to as the Lomonosov Terrace.

In the ACEX well, a tilted block composed of Campanian rocks underlies the Eocene deposits. The top Upper Cretaceous deposits may compose the postrift sedimentary cover of the Cretaceous grabens. Along the Lomonosov Ridge and its slope toward the Eurasian Basin, there is a system of half-grabens under the Eocene cover. Our correlation of the seismic complexes suggests that this system of half-grabens is filled with Paleocene deposits.

The subsidence history of the Lomonosov Ridge can be characterized on the basis of well data from the ACEX Project [Backman et al., 2008]. It is believed that 56.0-44.4 Ma ago, the territory of the ridge was a shallow sea. In the interval of 44.4-18.2 Ma, the territory could have been below the sea level; possibly, events of underwater erosion could have taken place. During the latest $18.2 \mathrm{Ma}$, the ridge block underwent subsidence down to the present-day depths. In the Quaternary 
A.M. Nikishin et al.: Rift systems of the Russian Eastern Arctic shelf...
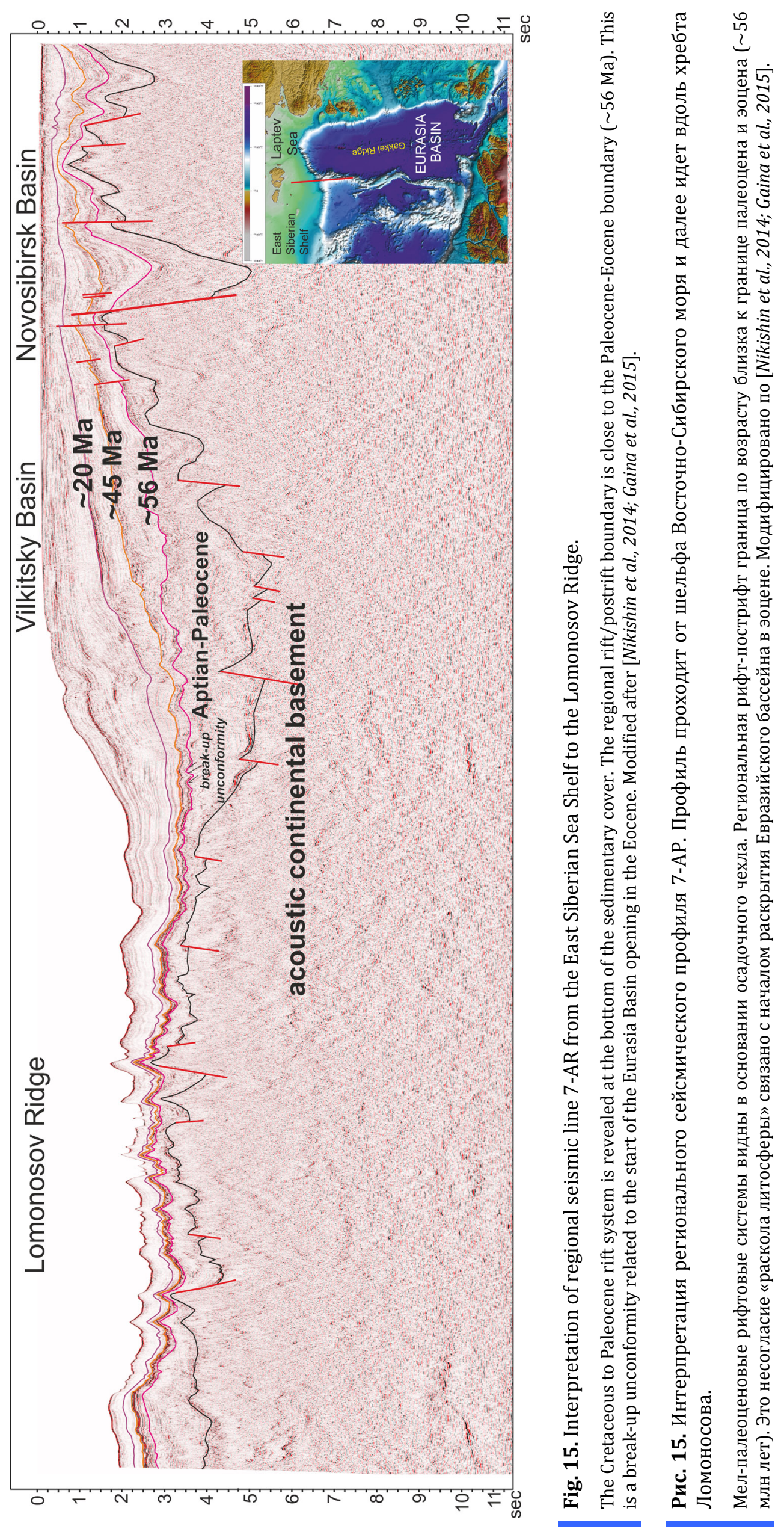


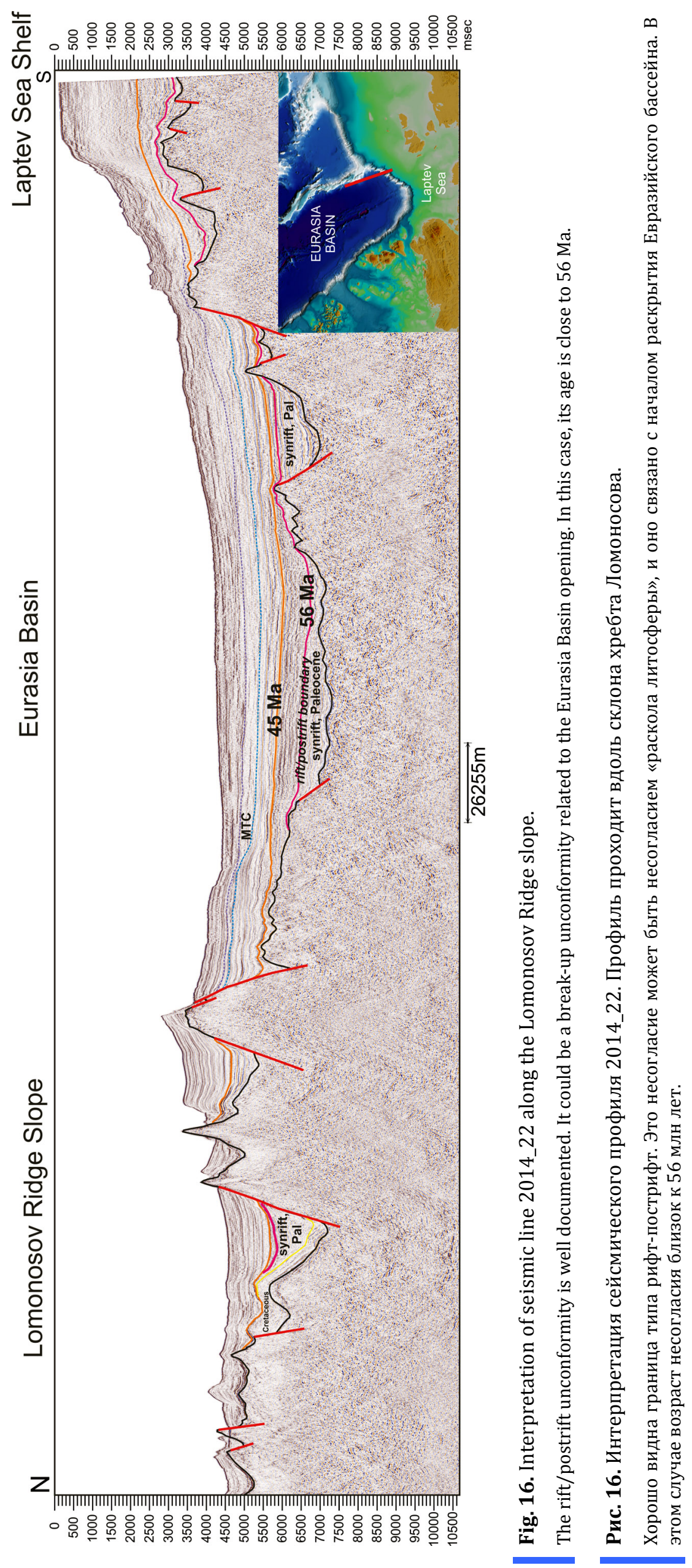




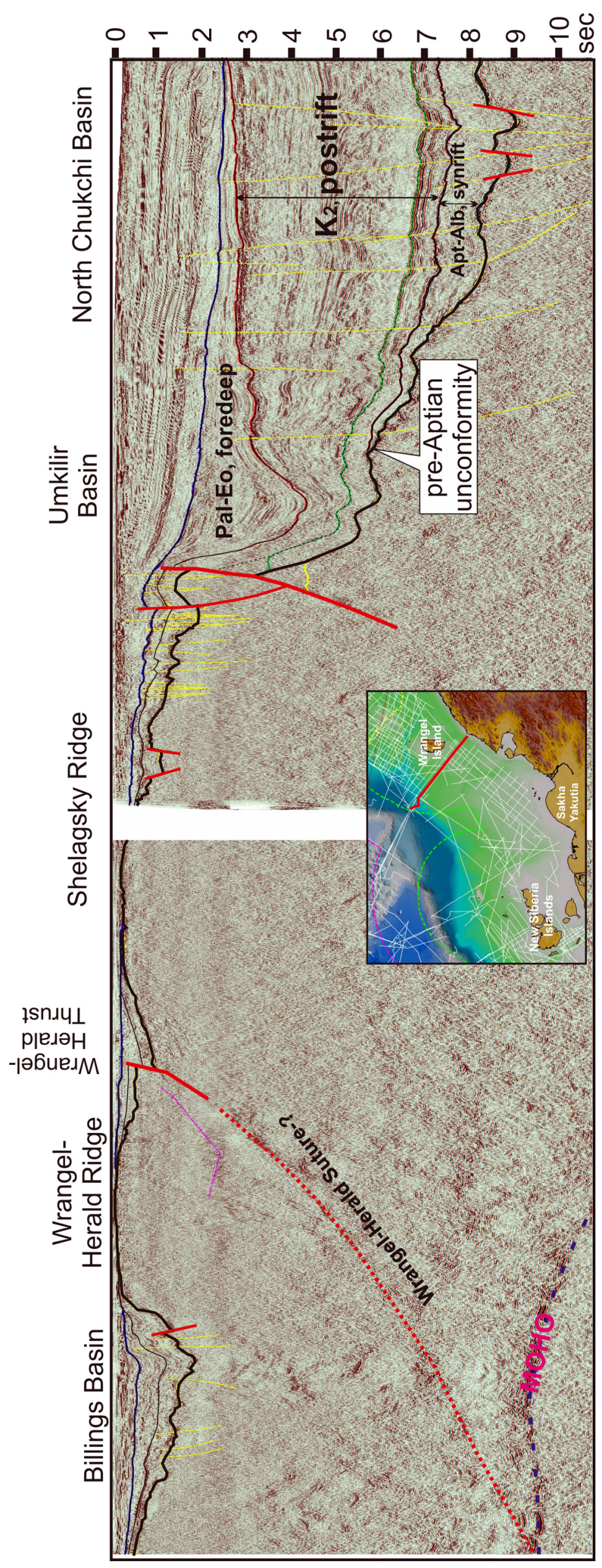

竞竞

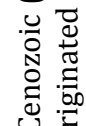

䒕 궁

$<\frac{\pi}{4}$

สี

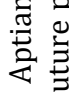

के

芠.

宅

สี

웅

可

需 0

过

政

壱

号

क

氙

릉 웅

递宽

존

这焉

究

'5

寻 䆑

옹

ชั

它

寻它

艺

壳

중

단

岢完

폰

表

它

응

究

용

중 웅

苋

空

象

곡

気

空

造

至

路

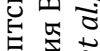

西

品突

दे 安

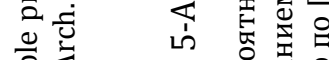

至

证

变

愙安

苟

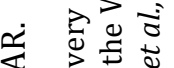

단

क

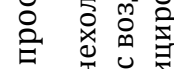

부

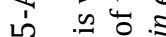

$\stackrel{0}{\Xi}$

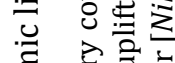

घ)

क छ

플

की

范

: 000

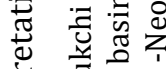

产 㐘它

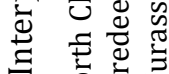

궁

它

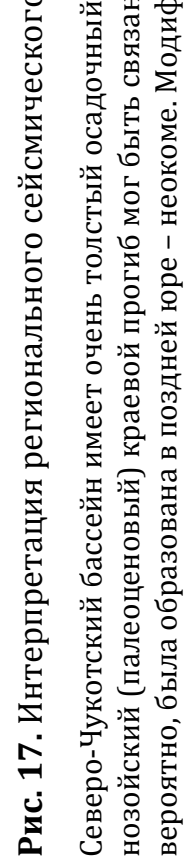


time, the Lomonosov Ridge was covered with glaciers several times, as evidenced by considerable glacier erosion [Jakobsson et al., 2008, 2014].

The Lomonosov Ridge is typical of numerous normal faults that were formed after $45 \mathrm{Ma}$ [Nikishin et al., 2014]. These faults dissect the Oligocene-Quaternary deposits. Many of these normal faults were formed through reactivation of Cretaceous and Paleocene normal faults.

From the side of the East Siberian Sea, the Lomonosov Ridge abuts against the shelf sedimentary basin. The character of this boundary is well seen on seismic lines (see Fig. 15). The seismic lines show that the bottom of the Aptian-Paleocene synrift sedimentary cover smoothly transits into the bottom of the Lomonosov Ridge's sedimentary cover. No boundaries at all are revealed along the basement of the East Siberian Shelf and the Lomonosov Ridge. A possible slip fault between the Lomonosov Ridge and the Siberian Shelf is discussed in [Pease et al., 2014; Doré et al., 2016]. In fact, structures of probable transpression are seen on some seismic lines in the zone of the slope [Gaina et al., 2015] (Figs. 21, 22). This may be a continuation of the Khatanga-Lomonosov fault zone. No data the KhatangaLomonosov Line is a regional transform fault with large horizontal movements. A model structure of the crust [Poselov et al., 2012] (see Fig. 15) shows that continental crust is continuously traced along seismic line 7-AR.

\section{GEOLOGICAL STRUCTURE OF THE DEEP-WATER PodvodNIKov Basin}

The Podvodnikov Basin can be divided into the Podvodnikov-Southern Basin, the Lomonosov Terrace in the west of the basin, and the buried Arlis Plateau in the north of the basin (see Figs. 4, 6, 10, 18, 19, and 20). The Podvodnikov-Southern Basin is bounded by fault zones on all sides. The boundary of the PodvodnikovSouthern Basin and the East Siberian Shelf is crossed by several seismic lines, that show a system of rift basins in the transition zone from the shelf to the Podvodnikov Basin. These rifts belong to the system of rifts of the East Siberian Sea wherein rifting occurred in the Aptian-Albian, according to our correlations. The seismic correlation reveals only this Aptian-Albian complex at the base of the section in the southern part of the Podvodnikov-Southern Basin. In the Podvodnikov-Southern Basin, synrift sediment complexes, that are triangular-shaped (wedge) in the section view, are clearly revealed at the base of the section, and the rift/postrift-type boundary is traced above them. The synrift complex of supposedly Aptian-Albian age is also well shown on seismic line ARC-2012-03 that runs along the continental slope (see Fig. 10). In our study, the seismostratigraphic boundary of $100 \mathrm{Ma}$ is the uppermost age boundary of the rifting period in this basin.

W. Jokat's group [Jokat et al., 2013; Weigelt et al., 2014] studied the Podvonnikov Basin and, based on interpretation of a single regional seismic line, made conclusions that are generally similar to ours. They also identify a number of rifts at the base of the sedimentary cover section. However, our model of the stratigraphy of the Podvodnikov Basin and their model are somewhat different.

\section{GeOlogical STRUCTURE OF THE MAKAROV BaSin}

The Makarov Basin is situated between the Lomonosov Ridge and the Alpha Ridge. In the south, it is separated from the Podvodnikov Basin by the buried Arlis Plateau. The Makarov Basin has a larger seabed depth (3-4 km) as compared to the Podvodnikov Basin and differs from it morphologically. In the plan view, the basin's shape is an isometric rhombus. The basin was described in [Jokat, 2005; Langinen et al., 2009; Lebedeva-Ivanova et al., 2011; Nikishin et al., 2014; Evangelatos, Mosher, 2016]. The sedimentary cover thickness in the basin reaches $2-4 \mathrm{~km}$. From the side of the Lomonosov Ridge, the basin is bounded by a system of normal faults. A similar normal-fault boundary is outlined with the Alpha Ridge as well. The basement of the basin has a ridge-trough relief. Such basement relief was, by all appearances, caused by rifting. Ridges and troughs of the basement, by the available data, have an east-west trend [Langinen et al., 2009]. The basin basement is probably composed of the continental crust strongly extended by rifling, though at some places the crystalline part of the crust is thinned to 8-12 $\mathrm{km}$, which may be indicative of the local presence of the oceanic crust [Langinen et al., 2009; LebedevaIvanova et al., 2011].

The Makarov Basin is crossed by Russian seismic lines ARC-14-06 andARC-14-07 [Nikishin et al., 2014]. The most important discovery in the Makarov Basin is a large-size structure classified as a buried rift, possibly trending near east-west. It is not yet clear whether this rift is a continental or an oceanic one.

The rhombic shape of the Makarov Basin in the plan view and its boundaries represented by the systems of normal faults may suggest that the basin has a transtensional origin like a pull-apart basin [Nikishin et al., 2014]. The trend of the axes of its rifting does not coincide with the trend of rifting axes in the Podvodnikov Basin. Would one admit that the axial rift is oceanic, then the Makarov Basin could be considered as a possible microoceanic basin of a pull-apart type inside the region with continental crust. The interrelationships of the Makarov Basin and the Alpha Ridge on seismic lines show that the Makarov Basin is probably 
A.M. Nikishin et al.: Rift systems of the Russian Eastern Arctic shelf...

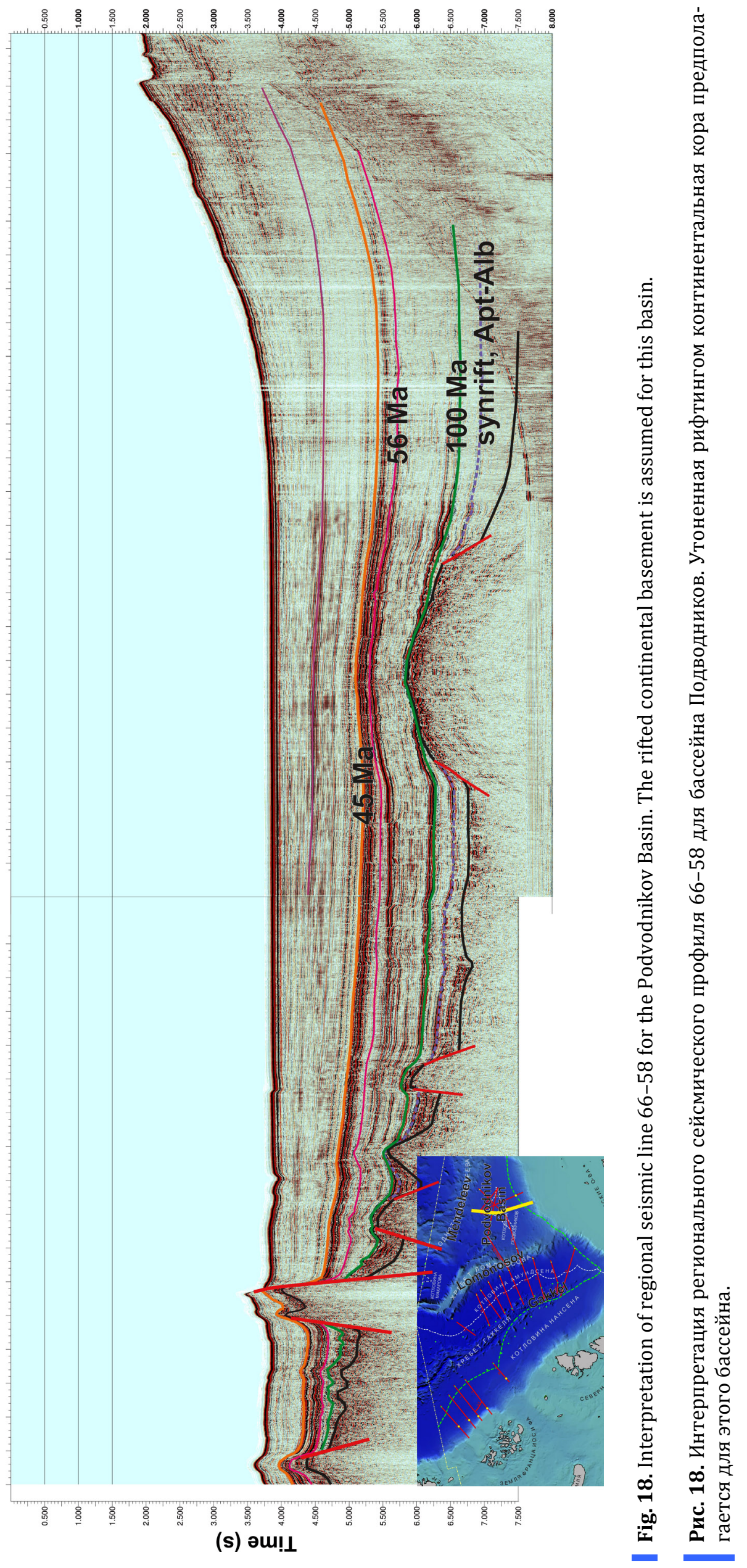




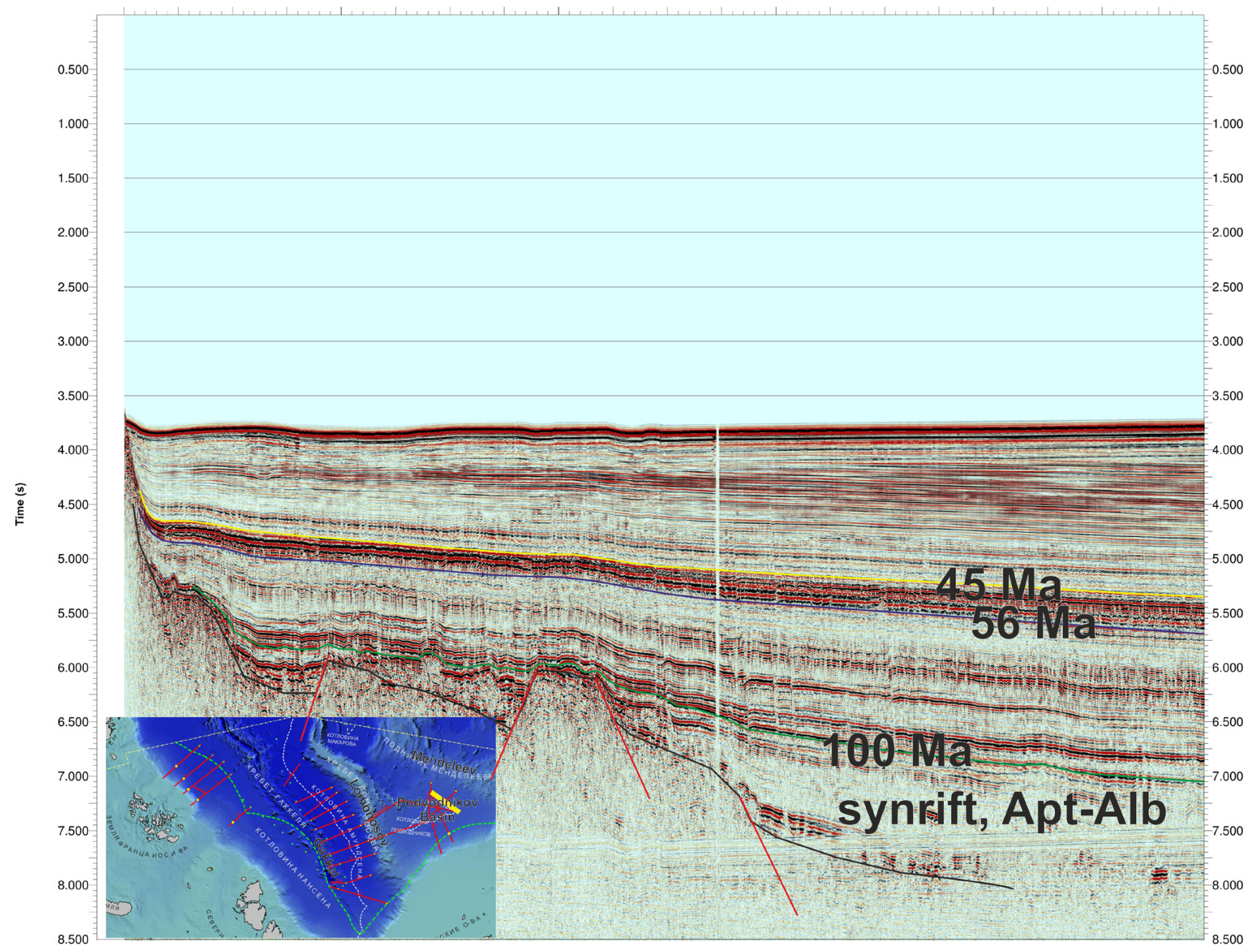

Fig. 19. Interpretation of regional seismic line 59-50 for the Podvodnikov Basin. The horst-graben structure of basement is documented. It means that the basement has the highly extended continental crust.

Рис. 19. Интерпретация регионального сейсмического профиля 59-50 для бассейна Подводников. Видна горст-грабеновая структура поверхности фундамента. Из этого следует, что фундамент бассейна сложен сильно растянутой континентальной корой.

younger than the Alpha-Mendeleev Ridge. Our seismostratigraphic correlation data show that rifting in the Makarov Basin took place earlier than $56 \mathrm{Ma}$, most probably at the end of Cretaceous - Paleocene. Thus, the Makarov Basin is younger than the Podvodnikov Basin.

\section{GeOlogical STRUCTURE OF THE CHUKCHI ABYSSAL Plain BASIN (OR THE TOLl BASIN) AND THE NAUTILUS BASIN}

The Chukchi Abyssal Plain Basin is situated between the Mendeleev Ridge and the Chukchi Plateau. For this basin, several new seismic lines are available from Arctic-2012 Project (see Fig. 6). Line 4200 directed from the North Chukchi Basin into the Chukchi Abyssal Plain Basin (see Fig. 9) shows that a package of bright reflec- tors not broken by faults lies at the base of the Chukchi Abyssal Plain Basin sedimentary cover. The structure of the acoustic basement is not revealed. In the Chukchi Abyssal Plain Basin, the thickness of sediments is 3.6 sec. This cover with the same basement smoothly transits in the cover of the North Chukchi Basin. On the seismic line, the base of the cover is seen poorly. But in the North Chukchi Basin, the sedimentary cover thickness reaches $10 \mathrm{sec}$. We suppose for the North Chukchi Basin that synrift sediments are of Aptian-Albian age, and the postrift cover began to form in the Upper Cretaceous. This implies that the postrift sedimentary section of the Chukchi Abyssal Plain Basin probably starts from the Upper Cretaceous.

Line ARC-2012-03 crosses the Chukchi Abyssal Plain Basin in its southern part (see Fig. 10). The Synrift-1 unit is located below the bottom of the section and forms packages of reflectors tilted to one side 


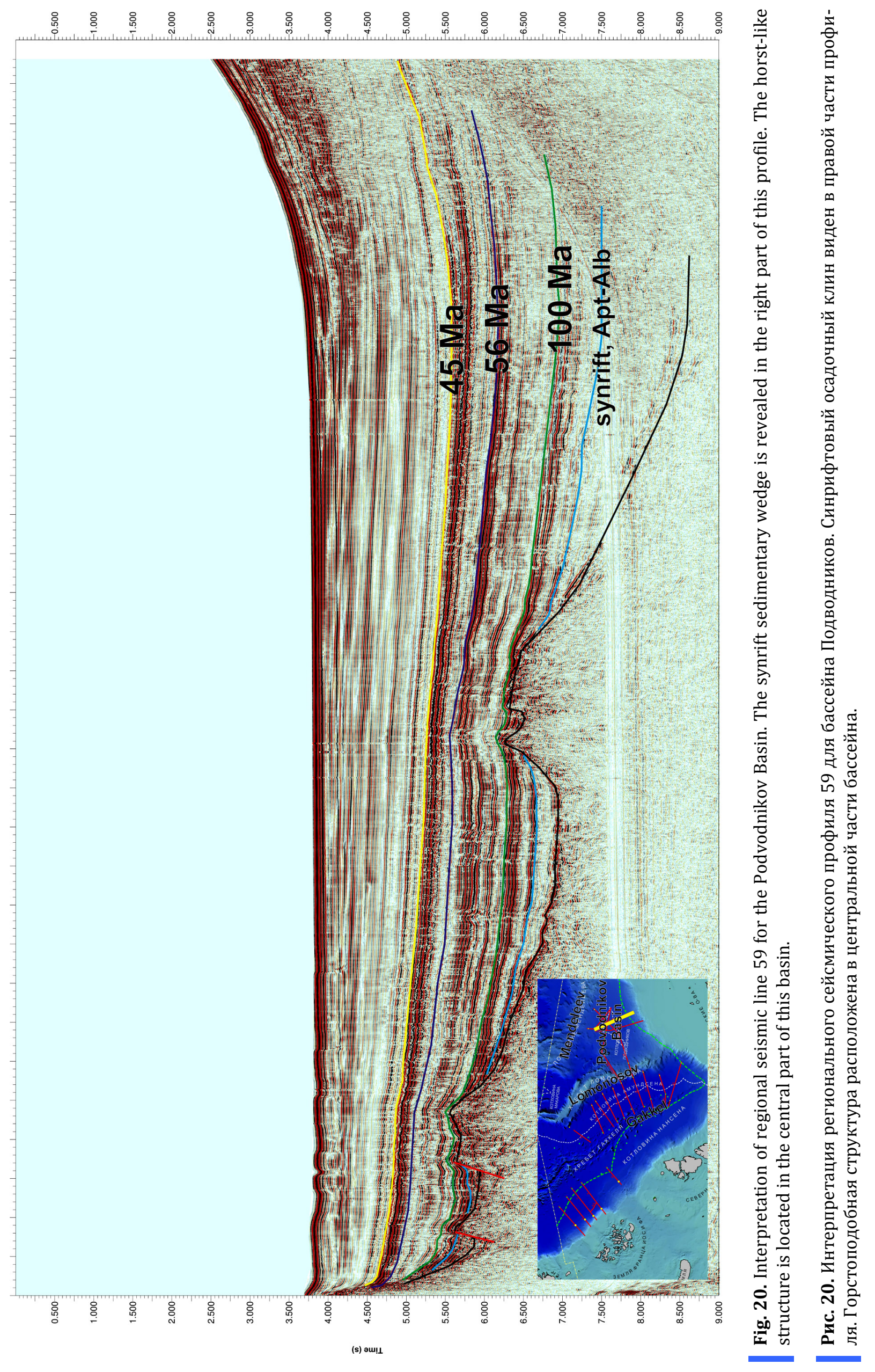




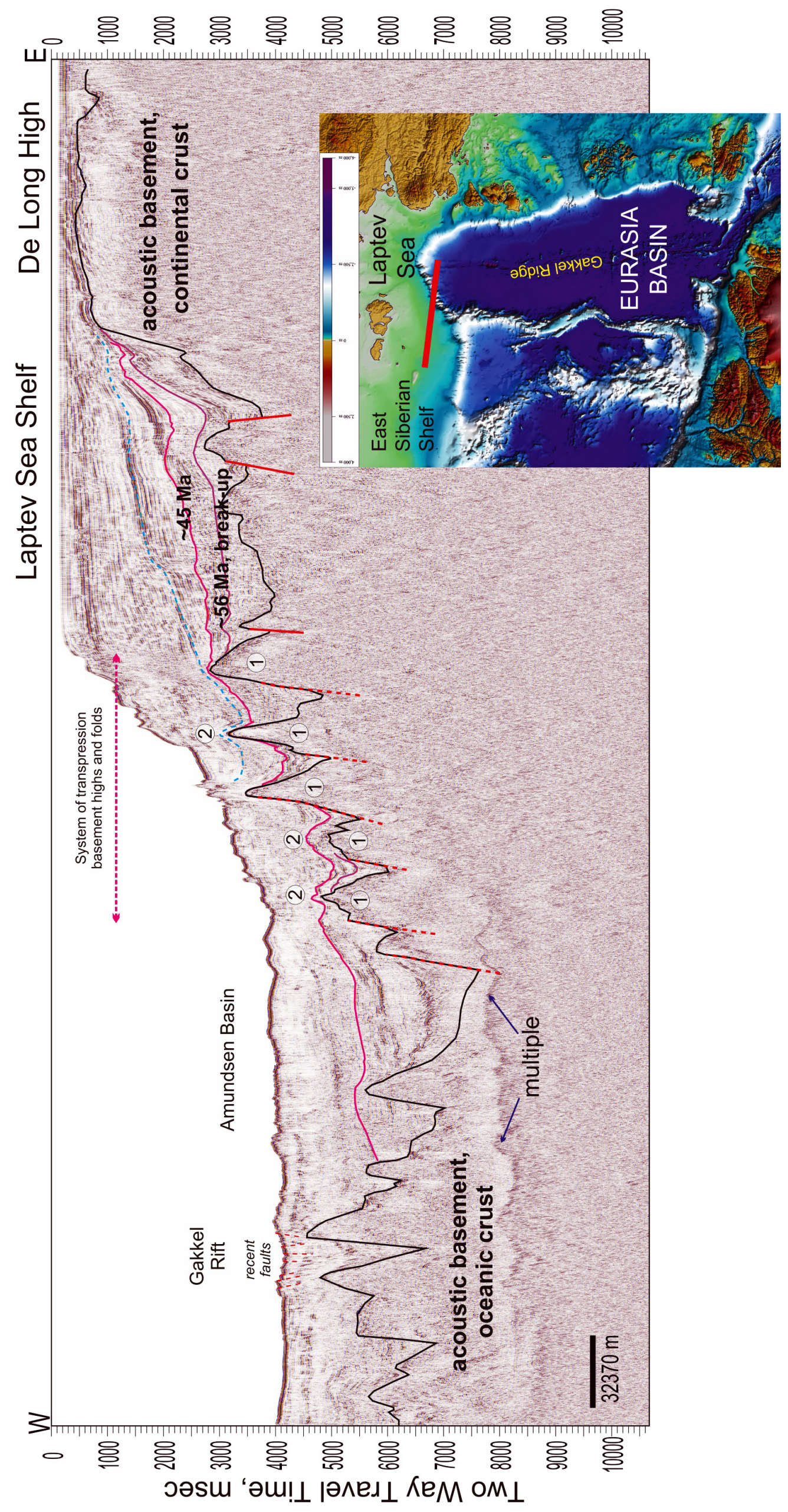

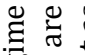

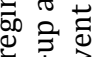

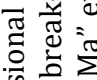

ฆ 논

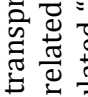

Q

ㄷํㅇำ

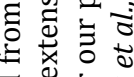

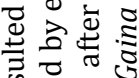

仓ั

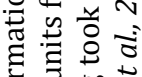

0 0

总苞苞

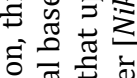

풘

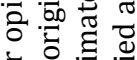

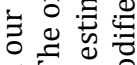

$\Xi \dot{\Sigma} \sum$

㲾方

离

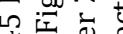

to

每

荡

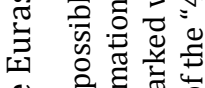

Q

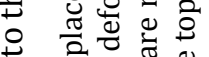

专

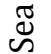

ฮี

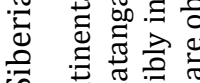

至

空

E

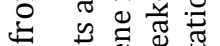

势鄂范

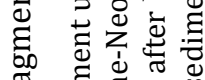

政

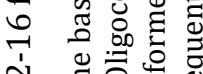

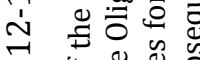

穴

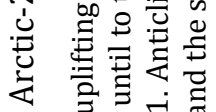

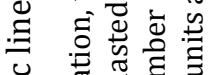

药

足

क षै

$\dot{\mathrm{N}} \mathrm{z}$

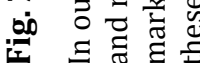

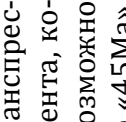

용

证

है

원

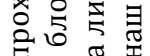

表

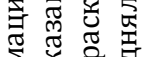

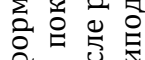

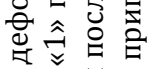

要

웅

는

ฮั่

壱吉志

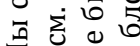

군

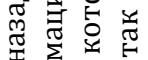

은

5.

运 5

苟 우월

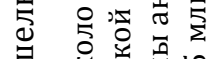

능 吕票 ᄂ

- 5 융요

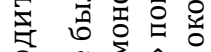

凶

을 5

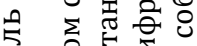

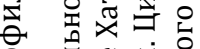

는

政 50.

$\rightarrow$ 잉

골

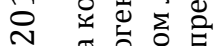

\%

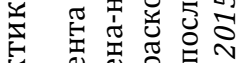

궁

『 5

5 ०

ㅂ.

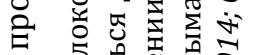

- 6 넝

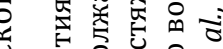

远

응

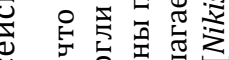

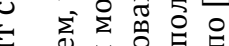

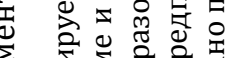

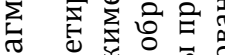

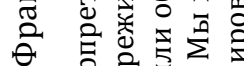

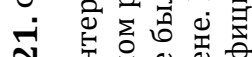

ㄱ.

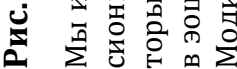


(westward), which gentle out up the section. The interpretation of this unit is ambiguous. It can be considered as a part of the acoustic basement because lower boundaries are not distinct. This unit looks like SDRtype reflectors, though it manifests itself only locally and on a single seismic line. We assume that the Synrift-1 unit is a synrift unit and is represented to a considerable extent by basaltic lavas. The boundary between the Synrift-1 and Postrift is expressed by a rift/postrift-type unconformity. We date the Synrift-1 as Aptain-Albian by analogy with the basalts on the De Long Islands. The synrift/postrift boundary is dated conventionally as $100 \mathrm{Ma}$. Some faults were reactivated after $100 \mathrm{Ma}$. The packages with bright reflectors at the base of the Mendeleev Ridge section may be interpretted as alternation of lavas and sediments.

Line ARC-2012-19 runs farther north than the previous one and is parallel to it (see Fig. 11). The interpretation of the line shows that no distinct boundaries are seen between the Chukchi Abyssal Plain Basin, the Mendeleev Ridge and the Chukchi Plateau. Only smooth transitions are observed between them. In the basin itself, the sedimentary cover thickness is about $1 \mathrm{sec}$. Peculiar features of the line are that along the basin's axis but closer to the Chukchi Plateau, a graben-like structure about 16-20 km wide is identified at the base of the sedimentary cover, and the thickness of the rift cover is about $1 \mathrm{sec}$. This structure is definitely of tectonic origin and is a graben. Two versions of a mechanism for formation of this graben are possible: (1) this is a graben on a continental crust, (2) this graben is a buried oceanic rift.

Line ARC-2012-04 runs farther north than the previous one and is parallel to it (see Fig. 6, A). An axial graben is also observed over there. It is also displaced from the axis of the basin toward the Chukchi Plateau. The width of the graben is $6 \mathrm{~km}$, and the thickness of the sedimentary cover in it is about $1 \mathrm{sec}$. Several more graben-like structures are outlined parallel to the axial graben. The graben on this line and on the previous one is probably one and the same structure. If so, then the axis of rifting in the Chukchi Abyssal Plain Basin was oriented in the N-S direction and was parallel to the axis of rifting on the Chukchi Plateau.

Summing up the data on the structure of the Chukchi Abyssal Plain Basin, the following conclusions and hypotheses can be formulated: (1) at the base of the basin, rifts exist, and at least in one of the rifts indications of synrift volcanism are available; (2) the axis of the rift had the N-S direction; (3) the transition from the Chukchi Abyssal Plain Basin to the Chukchi Plateau is smooth; (4) it can be supposed that the Cretaceous rifts of the Chukchi Abyssal Plain Basin and of the Chukchi Plateau were formed simultaneously on a continental crust; (5) it is probable that rifting in the Chukchi Abyssal Plain Basin and in the North Chukchi Basin took place simultaneously; these basins have a single sedimentary cover.

The Chukchi Abyssal Plain Basin was earlier characterized on the basis of seismic lines by the Alfred Wegener Institute [Hegewald, Jokat, 2013]. It was shown that the basement of the basin has a horst-graben structure with the north-south trends of grabens. The presence of basalt flow units is supposed. In the acoustic basement, packages of reflectors tilted to one side were found. These authors identified several phases of faulting: pre Cenozoic, pre Miocene, and younger ones. All these conclusions are consistent with our conclusions. The main differences between the assumptions in [Hegewald, Jokat, 2013] and our conclusions concern the age and basement type of the basin. Hegewald and Jokat believe that the basement is of Jurassic age and looks more like an oceanic crust. But they note that the axes of the spreading in this basin and in the Canada Basin are orthogonal to each other.

The Nautilus Basin is located between the Alpha Ridge (its southeastern part is named the Nautilus Spur) and the Chukchi Plateau. In fact, it is a gulf of the Canada Basin. Several seismic lines are available for this basin, which run from the Canada Basin toward the Nautilus Spur, crossing a part of the Nautilus Basin [Shimeld et al., 2011]. These lines show how the sedimentary cover of the Canada Basin covers the slope of the Nautilus Spur with onlap-type contacts. On the slope of the Nautilus Spur and at the slope of the sedimentary cover, low-amplitude normal faults are seen. On the slope of the Nautilus Basin, an erosional surface is distinctly revealed. On one of the seismic lines, a volcanic edifice is identified in the transition area of the Nautilus Basin into the Canada Basin. Judging from this seismic line, a $0.3 \mathrm{sec}$ thick strata of volcanites is identified [Shimeld et al., 2011].

The Russian seismic lines from Arctic-2012 Project cross the area of transition of the Mendeleev Ridge to Nautilus Basin (see Figs. 13, 14). Generally, the transition between the ridge and the basin is smooth. On the slope of the Mendeleev Ridge, numerous normal faults are observed at the base of the sedimentary cover.

The zone of transition from the Nautilus Basin to the Chukchi Plateau is named the Northern Chukchi Borderland. According to the hypothesis in [Brumley, 2009, 2014], this area is a deeply submerged part of the Chukchi Plateau because probable rift structures of the Chukchi Plateau are traced into this area.

\section{Geological structure OF THE ChUKChi Plateau}

The Chukchi Plateau consists of the Chukchi Plateau proper, the Northwind Ridge and the Northwind Basin separating them. All researchers believe that the Chukchi Plateau has a continental crust. Presently, a large 

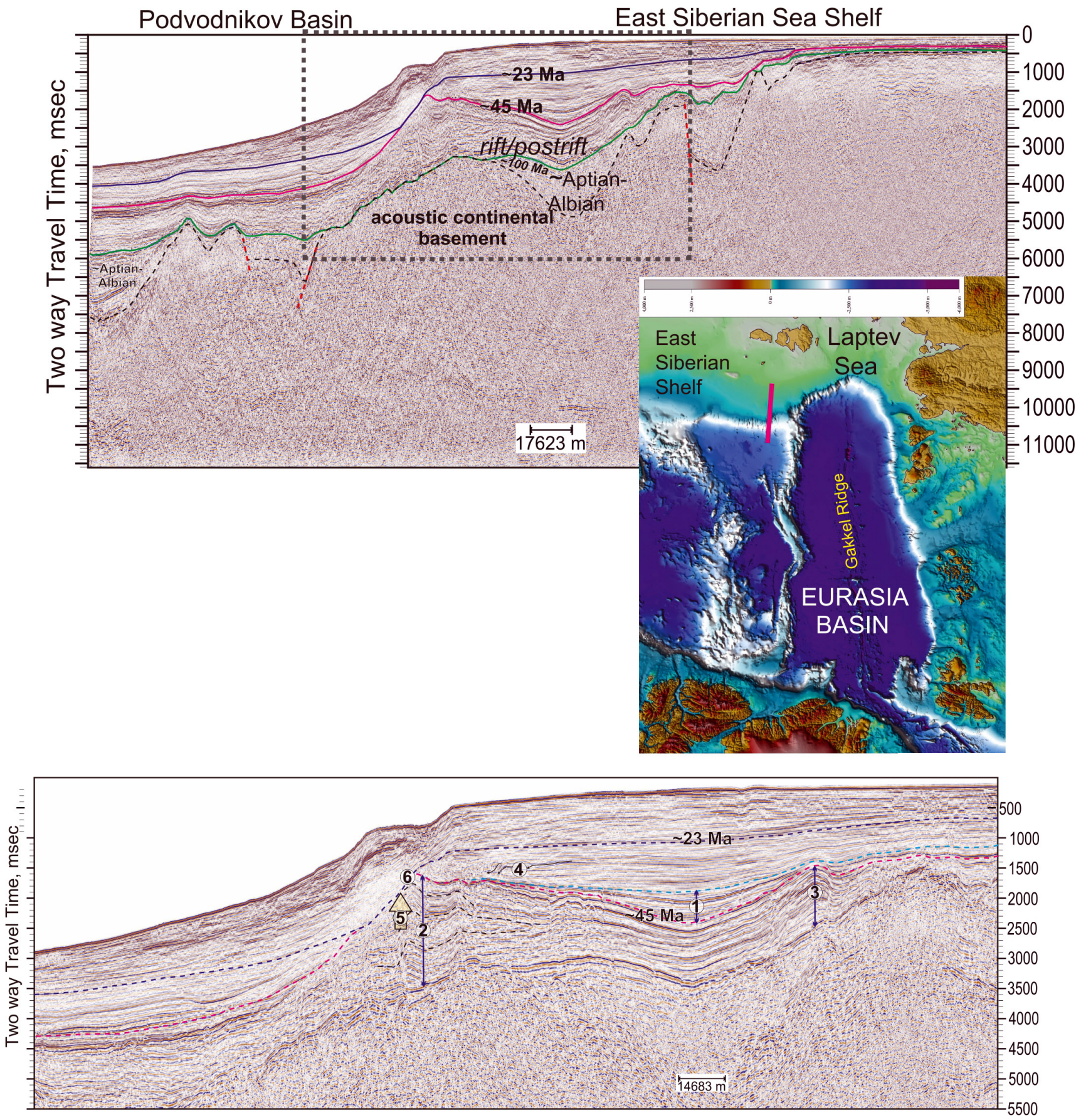

Fig. 22. Seismic line Arctic-2014-14 and the zoomed-in section.

Compression-related features (ca. 45-23 Ma) are revealed in the continental slope in the Khatanga-Lomonosov deformation zone (see Fig. 2). Numbers in white circles: Unit 1 - syntectonic and syncompressional deposition simultaneously with folding in units 2 and 3; Units 2 and 3 - folded mainly between the 45 Ma horizon and the "blue" horizon; Unit 4 - clinoform type of deposits with paleoslope towards the Podvodnikov Basin (Note: Unit 2 was not a topographic high/an uplift at that time); Unit/event 5 - Unit 2 together with the basement was uplifted before the horizon interpreted as "23 Ma"; Unit 6 - erosional surface on the slope (Note: Horizon "23 Ma" was deposited after tectonic uplifting of Unit 2 was complete). Modified after [Gaina et al., 2015].

Рис. 22. Сейсмический профиль Арктика-2014-14 и его увеличенный фрагмент.

Структуры сжатия с возрастом около 45-23 млн лет могут быть различимы на континентальном склоне в полосе ХатангаЛомоносовской зоны деформаций (см. рис. 2). Цифры в белых кружках показывают следующие события: единица «1» синтектоническая и синкомпрессионная седиментация одновременная со складчатостью в единицах «2» и «3»; единицы «2» и «3» были смяты в складки между горизонтом « 45 Ма» и «голубым» горизонтом. Единица «4»- клиноформный тип седиментации с палеосклоном в сторону бассейна Подводников, отметим, что в то время единица «2» еще не была поднятием. Единица-событие «5» показывает, что единица «2» вместе с фундаментом была поднята до горизонта, интерпретируемого как «23Ма». Единица «6»это эрозионная поверхность на склоне; горизонт «23Ма» был образован после окончания тектонического воздымания единицы «2». Модифицировано по [Gaina et al., 2015]. 
volume of seismic data is available concerning the structure of the Chukchi Plateau area [Arrigoni, 2008; Brumley, 2009, 2014; Grantz et al., 2011; Coakley, Ilhan, 2012; Mosher et al., 2012; Hegewald, Jokat, 2013].

Several seismic lines cross the boundary of the Chukchi Plateau and the Canada Basin [Brumley, 2014; Mosher et al., 2012]. Interpretation of these lines shows that this boundary is represented by a passive continental margin. No indications of compression structures are found [Mosher et al., 2012]. The boundary is very narrow, which, from our viewpoint, does not exclude that this boundary is of the transform continental margin type.

There are several seismic lines for the Chukchi Plateau itself, which are presented in [Arrigoni, 2008; Brumley, 2009, 2014; Coakley, Ilhan, 2012; Hegewald, Jokat, 2013]. On all of these lines, a system of horsts and grabens is identified. A synrift complex with sediments, triangular in the cross section, is readily identifiable in the grabens. Coakley and Ilhan [2012] identify synrift Mesozoic sediments and single out a later phase of transtensional tectonics. Hegewald and Jokat [2013] developed a new seismic stratigraphy for the Chukchi Plateau. They indentify, questionably, Cretaceous sediments in grabens, and the Top Oligocene and Top Miocene boundaries. According to their seismic stratigraphy model, grabens have definitely a Pre-Miocene age. They also identify a young Post Miocene phase of normal faulting.

Four Russian seismic lines from Arctic-2012 Project show the structure of the eastern part of the Chukchi Plateau (or the Chukchi Plateau proper) [Nikishin et al., 2014] (see Figs. 6, $A, 10,11,12$ ). High- amplitude reflective packages (HARPs) are often identified at the base of the sedimentary section. We suppose that these may be layers with horizons of basalt lavas. Such interpretation was suggested for similar formations in the Canada Basin [Lebedeva-Ivanova et al., 2013]. In the sedimentary cover, several tectonostratigraphic units with several phases of rifting can be singled out [ $\mathrm{Ni}$ kishin et al., 2014]. On one of the lines, synsedimentation compression folds are seen at the synrift/postrift boundary. The rift basins have probably experienced a phase of compression and a slight inversion. Considering that the phase of compression and folding in the area of the North Chukchi Basin was approximately at the boundary of Cretaceous and Paleogene [Sherwood et al., 2002; Verzhbitsky et al., 2012; 2015; Nikishin et al., 2014], a compression phase in the Chukchi Plateau area can also be dated approximately as the boundary of the Cretaceous and the Paleogene. On this ground, we date the age of the main rifting as Pre-Paleocene.

Seismic data for the Chukchi Plateau show that, probably at first, there was a basalt volcanism phase in the Cretaceous, and then the entire area of the presentdate plateau was subject to strong tension with for- mation of the horst-graben structure with the general $\mathrm{N}-\mathrm{S}$ trend. The width of individual horsts and halfgrabens is $20-30 \mathrm{~km}$. Generally, the system of Mesozoic rifts of the Chukchi Plateau is similar to the Cenozoic rift system of the Basin and Range Province in America [Nikishin et al., 2014]. This means that the Chukchi Plateau experienced a significant extension (up to 30$50 \%$ ) and had a thin lithosphere. In the Mid EoceneQuaternary, the Chukchi Plateau was subject to tension, and many Mesozoic normal faults were activated.

\section{GEOLOGICAL STRUCTURE OF THE ALPHA-MENDELEEV RISE}

The structure of the Alpha-Mendeleev Rise is described in [Jokat, 2003; Bruvoll et al., 2010, 2012; Dove et al., 2010; Døssing et al., 2013; Hegewald, Jokat, 2013; Weigelt et al., 2014; Brumley, 2014; Nikishin et al., 2014]. In this paper, we will not discuss its structure as a separate topic. Some seismic sections for this area are shown in Figs. 5, 13, and 14. It should be noted that it is commonly believed that this plateau is of volcanic origin. At the base of its sedimentary cover, Cretaceous grabens are identified [Brumley, 2014; Nikishin et al., 2014]. Many Cenozoic normal faults are also identified with the age younger than $45 \mathrm{Ma}$. The main discussion is going on concerning the problem of the basement of this plateau [Nikishin et al., 2014]. Some researches believe that the plateau has a thick crust of basaltic composition. Others state that the plateau has a continental basement with considerable rifting [Gaina et al., 2014; Pease et al., 2014]. In our opinion, the Alpha-Mendeleev Rise has a continental basement [Nikishin et al., 2014; Vernikovsky et al., 2014; Petrov et al., 2016].

\section{DisCuSSION}

Presently, it is only the formation time of the Eurasian Basin that is substantiated unambiguously -the basin started to open about $56 \mathrm{Ma}$. The formation history of the Amerasian Basin is still unclear, and various versions of its development are possible. One of the main problems is whether all the Amerasian basins (Canada, Podvodnikov, Makarov, etc.) were formed simultaneously or they have different ages [Alvey et al., 2008; Mosher et al., 2012; Grantz et al., 2011; Nikishin et al., 2014; Lawver et al., 2015; Doré et al., 2016].

Our seismic stratigraphic correlations give grounds for the following preliminary conclusions, although without a proper unambiguous substantiation yet:

(1) The Canada Basin probably had been formed before the Mid Aptian in the Early Cretaceous [Miller, Hudson, 1991; Helwig et al., 2011; Nikishin et al., 2014; Chain et al., 2016], though this issue remains debatable. 
(2) The Podvodnikov Basin started its formation not earlier than the Aptian. Our main arguments refer to the fact that the Mesozoic folding on the New Siberian Islands and on the Wrangel Island ended before the Aptian (or at the beginning of the Aptian). The Early Cretaceous (probably Aptian) De Long basalts were formed after a phase of significant erosion and overlie Paleozoic rocks of various ages with an angular unconformity. The seismic lines show that the De Long basalts occur at the base of some rifts of the East Siberian Sea. Hence, the time of rifting and transtensional tectonics in the East Siberian Sea cannot be older than the Aptian. The time of rifting in the North Chukchi Basin, according to our correlations, is also not older than the Aptian. The rifts on the continental margin of the Podvodnikov Basin cannot be older than these basins.

(3) According to our correlations, the belt of the basins - the Chukchi Abyssal Plain, Mendeleev, and Nautilus basins -was formed not earlier than the Aptian. This follows from the fact that rifting in the North Chukchi Basin was not earlier than the Aptian.

(4) The Makarov Basin is probably younger than the Podvodnikov Basin. The probable formation time of the Makarov Basin is Late Cretaceous - Paleocene. The basin probably was formed as a pull-apart structure.

At the present time, there are many reconstructions of the formation history of the Arctic Ocean [e.g., Alvey et al., 2008; Mosher et al., 2012; Grantz et al., 2011; Lawver et al., 2015]. It is obvious that models of different authors significantly differ. We believe that the Arctic Ocean probably has been formed during four phases with different kinematics. According to our model, the conventional boundaries of the different phases are: $133-125 \mathrm{Ma}, 125-78 \mathrm{Ma}, 78-56 \mathrm{Ma}$, and 56-0 Ma.

The boundaries of the first phase correspond to two regional unconformities on the Arctic Shelf of Alaska: $133 \mathrm{Ma}$ - the Lower Cretaceous Unconformity (LCU), $125 \mathrm{Ma}$ - the Brookian Unconformity (BU) [Sherwood et al., 2002]. According to our model, the LCU corresponds to the start of opening of the Canada Basin, while the BU to the end of formation of the Canada Ba$\sin$. The end of formation of the Canada Basin probably coincides with the start of the large-scale collapse of the Verkhoyansk-Chukotka orogen and the start of continental rifting in the East Siberian Sea and the Russian part of the Chukchi Sea [Miller, Verzhbitsky, 2009; Nikishin et al., 2014]. It is likely that approximately $125 \mathrm{Ma}$ a major rearrangement of the kinematics of the lithospheric plates took place. The collapse of the Verkhoyansk-Chukotka orogen and the start of the effect of the HALIP superplume corresponded to this rearrangement. In the Arctic, these processes resulted in formation of rift-related deep-water Podvodnikov Basin and the Chukchi Plain, Mendeleev, and Nautilus basins and the volcanic edifice of the Alpha-Mendeleev
Ridge on the continental crust strongly thinned by rifting. These processes lasted approximately till 78 Ma.

The approximate time of the end of subduction volcanism in the Okhotsk-Chukotka volcanic belt is $78 \mathrm{Ma}$ [Akinin, 2012]. After that, the Koryak-West Kamchatka accretionary orogen started to be formed [Soloviev, 2008; Akinin, 2012], and its formation completed about 50-45 Ma [Soloviev, 2008]. The end of subduction volcanism in the Okhotsk-Chukotka volcanic belt may correspond to the moment of significant rearrangement of the kinematics of plates and completion of the formation of the Alpha-Mendeleev Ridge.

Large-scale strike-slip deformations possibly took place from $78 \mathrm{Ma}$ to $56 \mathrm{Ma}$. As a results, the Makarov Basin was formed. These strike-slip deformations probably coordinated the plate kinematics in the Atlantic and Pacific regions.

Starting from $56 \mathrm{Ma}$ (or earlier), the formation history of the Arctic Ocean is related to the opening of the Atlantic Ocean, and the Eurasian Basin was formed.

\section{CONCLUSIONS}

The rift systems of the shelves of the Laptev, East Siberian and Chukchi Seas formed in connection with formation of the deep-water basins of the Arctic Ocean. The main rifting epoch was in the Aptian-Albian. It was synchronous with the start of formation of the Podvodnikov and Toll basins. The Aptian-Albian rifting took place just after the plume magmatism on the De Long Plateau, the Franz Joseph Land and in other places. The Makarov Basin probably was formed as a pull-apart basin later than the Podvodnikov Basin, between 78 and $56 \mathrm{Ma}$. The Eurasian Basin started to be formed approximately at the boundary of Paleocene and Eocene. Its formation is related to the development of the Atlantic Ocean.

\section{ACKNOWLEDGEMENTS}

The authors are grateful to Yu.B. Kazmin, I.F. Glumov, and A.F. Morozov for their useful discussions and support of the idea to publish this paper. We are thankful to V.A. Poselov, O.V. Petrov, A.B. Kuzmichev, L.I. Lobkovsky, V.A. Vernikovsky, V. Verzhbitsky, C. Gaina, E. Miller, V. Pease, W. Jokat, E. Weigelt, K. Brumley, A.G. Doré, and D. Mosher for sharing their views on Arctic geology. We appreciate the detailed discussions concerning the geology of the Arctic shelf seas with employees from Rosneft, Total, and ION. We are thankful to O. Aleshina, A. Popova, and E. Bulgakova for assistance with the seismic data interpretation and discussions. 


\section{REFERENCES}

Akinin V.V., 2012. Late Mesozoic and Cenozoic Magmatism and Lower Crust Modifications in the Northern Framing of Pacific. Doctor of Sci. dissertation. IGEM RAS, Moscow, 320 p. (in Russian) [Акинин В.В. Позднемезозойский и кайнозойский магматизм и преобразование нижней коры в северном обрамлении Пацифики: Дис. ... докт. геол.-мин. наук. М.: ИГЕМ РАН, 2012. 320 с.].

Alvey A., Gaina C., Kushner N.J., Torsvik T.H., 2008. Integrated crustal thickness mapping and plate reconstructions for the high Arctic. Earth and Planetary Science Letters 274 (3-4), 310-321. https://doi.org/10.1016/j.epsl.2008. 07.036.

Andronikov A., Mukasa S., Mayer L.A., Brumley K., 2008. First Recovery of submarine basalts from the Chukchi Borderland and Alpha / Mendeleev Ridge region, Arctic Ocean. Eos, Transactions American Geophysical Union 89 (53), Fall Meet. Suppl., Abstract V41D-2124.

Arrigoni V., 2008. Origin and Evolution of the Chukchi Borderland. A Thesis. Submitted to the Office of Graduate Studies of Texas A\&M University in partial fulfillment of the requirements for the degree of Master of Science. $64 \mathrm{p}$.

Backman J., Jakobsson M., Frank M., Sangiorgi F., Brinkhuis H., Stickley C., O'Regan M., Løvlie R., Pälike H., Spofforth D., Gattacecca J., Moran K., King J., Heil C., 2008. Age model and core-seismic integration for the Cenozoic Arctic Coring Expedition sediments from the Lomonosov Ridge. Paleoceanography 23 (1), PA1S03. https://doi.org/10.1029/ 2007PA001476.

Brumley K., 2009. Tectonic geomorphology of the Chukchi Borderland: constraint for tectonic reconstruction models. A Thesis presented to the faculty of the University of Alaska Fairbanks in partial fulfillment of the requirements for the degree of Master of Science, $124 \mathrm{p}$.

Brumley K., 2014. Geologic history of the Chukchi Borderland, Arctic Ocean. A dissertation submitted to the department of geology and environmental sciences and the committee on graduate studies of Stanford university in partial fulfillment of the requirements for the degree of Doctor of philosophy. Available from: http://purl.stanford. edu/hz857zk1405.

Bruvoll V., Kristoffersen Y., Coakley B.J., Hopper J.R., 2010. Hemipelagic deposits on the Mendeleev and northwestern Alpha submarine Ridges in the Arctic Ocean: acoustic stratigraphy, depositional environment and an inter-ridge correlation calibrated by the ACEX results. Marine Geophysical Researches 31 (3), 149-171. https://doi.org/ 10.1007/s11001-010-9094-9.

Bruvoll V., Kristoffersen Y., Coakley B.J., Hopper J.R., Planke S., Kandilarov A., 2012. The nature of the acoustic basement on Mendeleev and northwestern Alpha ridges, Arctic Ocean. Tectonophysics 514-517, 123-145. https://doi.org/ 10.1016/j.tecto.2011.10.015.

Chian D., Jackson H.R., Hutchinson D.R., Shimeld J.W., Oakey G.N., Lebedeva-Ivanova N., Li Q. Saltus R.W., Mosher D.C., 2016. Distribution of crustal types in Canada Basin, Arctic Ocean. Tectonophysics 691 (Part A), 8-30. https:// doi.org/10.1016/j.tecto.2016.01.038.

Coakley B., Ilhan I., 2012. Developing geophysical constraints on the history of the Amerasian Basin of the Arctic Ocean. Offshore Technology Conference, OTC 23795.

Cochran J.R., 2008. Seamount volcanism along the Gakkel Ridge, Arctic Ocean. Geophysical Journal International 174 (3), 1153-1173. https://doi.org/10.1111/j.1365-246X.2008.03860.x.

Corfu F., Polteau S., Planke S., Faleide J.I., Svensen H., Zayoncheck A., Stolbov N., 2013. U-Pb geochronology of Cretaceous magmatism on Svalbard and Franz Josef Land, Barents Sea large igneous province. Geological Magazine 150 (06), 1127-1135. https://doi.org/10.1017/S0016756813000162.

Dick H.J., Lin J., Schouten H., 2003. An ultraslow-spreading class of ocean ridge. Nature 426 (6965), 405-412. https://doi.org/10.1038/nature02128.

Dobretsov N.L., Vernikovsky V.A., Karyakin Yu.V., Korago E.A., Simonov V.A., 2013. Mesozoic-Cenozoic volcanism and geodynamic events in the Central and Eastern Arctic. Russian Geology and Geophysics 54 (8), 874-887. https:// doi.org/10.1016/j.rgg.2013.07.008.

Doré A.G., Lundin E.R., Gibbons A., Sømme T.O., Tørudbakken B.O., 2016. Transform margins of the Arctic: a synthesis and re-evaluation. In: M. Nemćok, S. Rybár, S.T. Sinha, S.A. Hermeston, L. Ledvényiové (Eds.), Transform margins: development, controls and petroleum systems. Geological Society, London, Special Publications, vol. 431, p. 63-94. https://doi.org/10.1144/SP431.8.

Døssing A., Jackson H.R., Matzka J., Einarsson I., Rasmussen T.M., Olesen A.V., Brozena J.M., 2013. On the origin of the Amerasia Basin and the High Arctic Large Igneous Province - results of new aeromagnetic data. Earth and Planetary Science Letters 363, 219-230. https://doi.org/10.1016/j.epsl.2012.12.013.

Dove D., Coakley B., Hopper J., Kristoffersen Y., Team H.G., 2010. Bathymetry, controlled source seismic and gravity observations of the Mendeleev ridge; implications for ridge structure, origin, and regional tectonics. Geophysical Journal International 183 (2), 481-502. https://doi.org/10.1111/j.1365-246X.2010.04746.x.

Drachev S.S., 2016. Fold belts and sedimentary basins of the Eurasian Arctic. Arktos 2, 21. https://doi.org/10.1007/ s41063-015-0014-8.

Drachev S.S., Malyshev N.A., Nikishin A.M., 2010. Tectonic history and petroleum geology of the Russian Arctic Shelves: an overview. In: B.A. Vining, S.C. Pickering (Eds.), Petroleum Geology: From Mature Basins to New Frontiers - Pro- 
ceedings of the 7th Petroleum Geology Conference. Geological Society, London, Petroleum Geology Conference series, vol. 7, p. 591-619. https://doi.org/10.1144/0070591.

Drachev S., Saunders A.D., 2006. The Early Cretaceous Arctic Lip: its geodynamic setting and implications for Canada Basin opening. In: R.A. Scott, D.K. Thurston (Eds.), Proceedings of the Fourth International Conference on Arctic Margins ICAM IV. US Department of the Interior, p. 216-223.

Ehlers B.-M., Jokat $W$., 2009. Subsidence and crustal roughness of ultra-slow spreading ridges in the northern North Atlantic and in the Arctic Ocean. Geophysical Journal International 177 (2), 451-462. https://doi.org/10.1111/ j.1365-246X.2009.04078.x.

Elkins L.J., Sims K.W.W., Prytulak J., Blichert-Toft J., Elliott T., Blusztajn J., Fretzdorff S., Reagan M., Haase K., Humphris S., Schilling J.-G., 2014. Melt generation beneath Arctic Ridges: Implications from U decay series disequilibria in the Mohns, Knipovich, and Gakkel Ridges. Geochimica et Cosmochimica Acta 127, 140-170. https://doi.org/10.1016/ j.gca.2013.11.031.

Evangelatos J., Mosher D.C., 2016. Seismic stratigraphy, structure and morphology of Makarov Basin and surrounding regions: tectonic implications. Marine Geology 374, 1-13. https://doi.org/10.1016/j.margeo.2016.01.013.

Franke D., 2013. Rifting, lithosphere breakup and volcanism: Comparison of magma-poor and volcanic rifted margins. Marine and Petroleum Geology 43, 63-87. https://doi.org/10.1016/j.marpetgeo.2012.11.003.

Gaina C., Medvedev S., Torsvik T.H., Koulakov I., Werner S.C., 2014. 4D Arctic: a glimpse into the structure and evolution of the Arctic in the light of new geophysical maps, plate tectonics and tomographic models. Surveys in Geophysics 35 (5), 1095-1122. https://doi.org/10.1007/s10712-013-9254-y.

Gaina G., Nikishin A.M., Petrov E.I., 2015. Ultraslow spreading, ridge relocation and compressional events in the East Arctic region - A link to the Eurekan orogeny? Arktos 1, 16. https://doi.org/10.1007/s41063-015-0006-8.

Gaina C., Werner S.C., Saltus R., Maus S., 2011. Circum-Arctic mapping project: new magnetic and gravity anomaly maps of the Arctic. In: A.M. Spencer, A.F. Embry, D.L. Gautier, A.V. Stoupakova, K. Sørensen (Eds.), Arctic Petroleum Geology. Geological Society, London, Memoirs, vol. 35, p. 39-48. https://doi.org/10.1144/M35.3.

Glebovsky V.Yu., Astafurova E.G., Chernykh A.A., Korneva M.A., Kaminsky V.D., Poselov V.A., 2013. Thickness of the Earth's crust in the deep Arctic Ocean: Results of a 3D gravity modeling. Russian Geology and Geophysics 54 (3), 247-262. https://doi.org/10.1016/j.rgg.2013.02.001.

Glebovsky V.Yu., Kaminsky V.D., Minakov A.N., Merkur'ev S.A., Childers V.A., Brozena J.M., 2006. Formation of the Eurasia Basin in the Arctic Ocean as inferred from geohistorical analysis of the anomalous magnetic field. Geotectonics 40 (4), 263-281. https://doi.org/10.1134/S0016852106040029.

Grantz A., Scott R.A., Drachev S.S., Moore T.E., Valin Z.C., 2011. Chapter 2. Sedimentary successions of the Arctic Region $\left(58-64^{\circ}\right.$ to $\left.90^{\circ} \mathrm{N}\right)$ that may be prospective for hydrocarbons. In: A.M. Spencer, A.F. Embry, D.L. Gautier, A.V. Stoupakova, K. Sørensen (Eds.), Arctic Petroleum Geology. Geological Society, London, Memoirs, vol. 35, p. 17-37. https://doi.org/10.1144/M35.2.

Hegewald A., Jokat W., 2013. Tectonic and sedimentary structures in the northern Chukchi region, Arctic Ocean. Journal of Geophysical Research: Solid Earth 118 (7), 3285-3296. https://doi.org/10.1002/jgrb.50282.

Helwig J., Kumar N., Emmet P., Dinkelman M.G., 2011. Regional seismic interpretation of crustal framework, Canadian Arctic passive margin, Beaufort Sea, with comments on petroleum potential. In: A.M. Spencer, A.F. Embry, D.L. Gautier, A.V. Stoupakova, K. Sørensen (Eds.), Arctic Petroleum Geology. Geological Society, London, Memoirs, vol. 35, p. 527-543. https://doi.org/10.1144/M35.35.

Ikhsanov B., 2014. Late Mesozoic and Cenozoic Deformations of Sedimentary Basins of Chukchi Sea. PhD Thesis. Moscow State University, Geological Faculty, Moscow, 116 p. (in Russian) [Ихсанов Б.И. Позднемезозойские и кайнозойские деформации осадочных бассейнов акватории Чукотского моря: Дис. ... канд. геол.-мин. наук. М: МГУ, геологический факультет, 2014. 116 с.].

Jakobsson M., Andreassen K., Bjarnadóttir L.R., Dove D., Dowdeswell J.A., England J.H., Funder S., Hogan K., Ingólfsson Ó., Jennings A., Larsen N.K., Kirchner N., Landvik J.Y., Mayer L., Mikkelsen N., Möller P., Niessen F., Nilsson J., O'Regan M., Polyak L., Nørgaard-Pedersen N., Stein R., 2014. Arctic Ocean glacial history. Quaternary Science Reviews 92, 40-67. https://doi.org/10.1016/j.quascirev.2013.07.033.

Jakobsson M., Polyak L., Edwards M., Kleman J., Coakley B., 2008. Glacial geomorphology of the Central Arctic Ocean: the Chukchi Borderland and the Lomonosov Ridge. Earth Surface Processes and Landforms 33 (4), 526-545. https:// doi.org/10.1002/esp.1667.

Jokat W., 2003. Seismic investigations along the western sector of Alpha Ridge, Central Arctic Ocean. Geophysical Journal International 152 (1), 185-201. https://doi.org/10.1046/j.1365-246X.2003.01839.x.

Jokat $W$., 2005. The sedimentary structure of the Lomonosov Ridge between $88^{\circ} \mathrm{N}$ and $80^{\circ} \mathrm{N}$. Geophysical Journal International 163 (2), 698-726. https://doi.org/10.1111/j.1365-246X.2005.02786.X.

Jokat W., Ickrath M., 2015. Structure of ridges and basins off East Siberia along $81^{\circ} \mathrm{N}$, Arctic Ocean. Marine and Petroleum Geology 64, 222-232. https://doi.org/10.1016/j.marpetgeo.2015.02.047.

Jokat W., Ickrath M., O'Connor J., 2013. Seismic transect across the Lomonosov and Mendeleev Ridges: Constraints on the geological evolution of the Amerasia Basin, Arctic Ocean. Geophysical Research Letters 40 (19), 5047-5051. https://doi.org/10.1002/grl.50975. 
Khoroshilova M.A., Franke D., Kirillova T., Mouly B., Nikishin A.M., 2014. Dating and correlation of reference seismic horizons in the Laptev Sea basin. Moscow University Geology Bulletin 69 (5), 271-280. https://doi.org/10.3103/ S0145875214050032.

Kim B.I., Glezer Z.I., 2007. Sedimentary cover of the Lomonosov Ridge: stratigraphy, structure, deposition history, and ages of seismic facies units. Stratigraphy and Geological Correlation 15 (4), 401-420. https://doi.org/10.1134/ S0869593807040053.

Kos'ko M.K., Sobolev N.N., Korago E.A., Proskurnin V.F., Stolbov N.M., 2013. Geology of Novosibirskian Islands - a basis for interpretation of geophysical data on the Eastern Arctic shelf of Russia. Neftegazovaya Geologiya. Teoriya $i$ Praktika 8 (2), Article 17 (in Russian) [Косько М.К., Соболев Н.Н., Кораго Е.А., Проскурнин В.Ф., Столбов Н.М. Геология Новосибирских островов - основа интерпретации геофизических данных по Восточно-Арктическому шельфу России // Нефтегазовая геология. Теория и практика. 2013. Т. 8. № 2. Статья 17]. Available from: http://www.ngtp.ru/rub/5/17_2013.pdf.

Kos'ko M.K., Cecile M.P., Harrison J.C., Ganelin V.G., Khandoshko N.V., Lopatin B.G., 1993. Geology of Wrangel Island, Between Chukchi and East Siberian Seas, Northeastern Russia. Geological Survey Canada Bulletin, vol. 461, 101 p.

Kos'ko M.K., Trufanov G.V., 2002. Middle Cretaceous to Eopleistocene Sequences on the New Siberian Islands: an approach to interpret offshore seismic. Marine and Petroleum Geology 19 (7), 901-919. https://doi.org/10.1016/ S0264-8172(02)00057-0.

Kumar N., Granath J.W., Emmet P.A., Helwig J.A., Dinkelman M.G., 2011. Stratigraphic and tectonic framework of the US Chukchi Shelf: exploration insights from a new regional deep-seismic reflection survey. In: A.M. Spencer, A.F. Embry, D.L. Gautier, A.V. Stoupakova, K. Sørensen (Eds.), Arctic Petroleum Geology. Geological Society, London, Memoirs, vol. 35, p. 501-508. https://doi.org/10.1144/M35.33.

Kuzmichev A.B., 2009. Where does the South Anyui suture go in the New Siberian islands and Laptev Sea? Implications for the Amerasia basin origin. Tectonophysics 463 (1-4), 86-108. https://doi.org/10.1016/j.tecto.2008.09.017.

Kuzmichev A.B., Aleksandrova G.N., Herman A.B., 2009. Aptian-Albian coaliferous sediments of Kotel'nyi Island (New Siberian Islands): new data on the section structure and ignimbrite volcanism. Stratigraphy and Geological Correlation 17 (5), 519-543. https://doi.org/10.1134/S0869593809050050.

Kuzmichev A.B., Aleksandrova G.N., Herman A.B., Danukalova M.K., Simakova A.N., 2013. Paleogene-Neogene sediments of Bel'kov Island (New Siberian Islands): characteristics of sedimentary cover in the Eastern Laptev Shelf. Stratigraphy and Geological Correlation 21 (4), 421-444. https://doi.org/10.1134/S0869593813040059.

Langinen A.E., Lebedeva-Ivanova N.N., Gee D.G., Zamansky Y.Y., 2009. Correlations between the Lomonosov Ridge, Marvin Spur and adjacent basins of the Arctic Ocean based on seismic data. Tectonophysics 472 (1-4), 309-322. https://doi.org/10.1016/j.tecto.2008.05.029.

Laverov N.P., Lobkovsky L.I., Kononov M.V., Dobretsov N.L., Vernikovsky V.A., Sokolov S.D., Shipilov E.V., 2013. A geodynamic model of the evolution of the Arctic basin and adjacent territories in the Mesozoic and Cenozoic and the outer limit of the Russian Continental Shelf. Geotectonics 47 (1), 1-30. https://doi.org/10.1134/S00168521130 10044.

Lawver L., Norton I., Garagan L., 2015. The bigger picture: a need for the whole Earth plate tectonic setting when reconstructing Greenland. 3P Arctic. The Polar Petroleum Potential. Conference \& Exibition. Stavanger, Abstracts, p. 61.

Lebedeva-Ivanova N.N., Gee D.G., Sergeyev M.B., 2011. Crustal structure of the East Siberian continental margin, Podvodnikov and Makarov basins, based on refraction seismic data (TransArctic 1989-1991). In: A.M. Spencer, A.F. Embry, D.L. Gautier, A.V. Stoupakova, K. Sørensen (Eds.), Arctic Petroleum Geology. Geological Society, London, Memoirs, vol. 35, p. 395-411. https://doi.org/10.1144/M35.26.

Lebedeva-Ivanova N., Hutchinson D., Shimeld J., Chian D., Hart R., Jackson R., Saltus R., Mosher D., 2013. Possible origin of high-amplitude reflection packages (HARPs) in the Canada Basin, Arctic Ocean. Geophysical Research Abstracts 15, EGU2013-11412. Available from: http://meetingorganizer.copernicus.org/EGU2013/EGU2013-11412.pdf.

Michael P.J., Langmuir C.H., Dick H.J.B., Snow J.E., Goldstein S.L., Graham D.W., Lehnert K., Kurras G., Jokat W., Mühe R., Edmonds H.N., 2003. Magmatic and amagmatic seafloor generation at the ultraslow-spreading Gakkel ridge, Arctic Ocean. Nature 423 (6943), 956-961. https://doi.org/10.1038/nature01704.

Miller E.L., Gehrels G.E., Pease V., Sokolov S., 2010. Stratigraphy and U-Pb detrital zircon geochronology of Wrangel Island, Russia: Implications for Arctic paleogeography. AAPG Bulletin 94 (5), 665-692. https://doi.org/10.1306/ 10200909036.

Miller E.L., Hudson T.L., 1991. Mid-Cretaceous extensional fragmentation of a Jurassic-Early Cretaceous compressional orogen, Alaska. Tectonics 10 (4), 781-796. https://doi.org/10.1029/91TC00044.

Miller E.L., Soloviev A., Kuzmichev A., Gehrels G., Toro J., Tuchkova M., 2008, Jura-Cretaceous foreland basin deposits of the Russian Arctic: Separated by birth of Makarov Basin? Norwegian Journal of Geology 88 (4), 201-226.

Miller E., Verzhbitsky V., 2009. Structural studies near Pevek, Russia: implications for formation of the East Siberian Shelf and Makarov Basin of the Arctic Ocean. In: D.B. Stone, K. Fujita, P.W. Layer, E.L. Miller, A.V. Prokopiev, J. Toro (Eds.), Geology, geophysics and tectonics of Northeastern Russia: a tribute to L. Parfenov. Stephan Mueller Special Publication Series, vol. 4, p. 223-241. https://doi.org/10.5194/smsps-4-223-2009. 
Moore T.E., O'Sullivan P.B., Potter C.J., Donelick R.A., 2015. Provenance and detrital zircon geochronologic evolution of lower Brookian foreland basin deposits of the western Brooks Range, Alaska, and implications for early Brookian tectonism. Geosphere 11 (1), 93-122. https://doi.org/10.1130/GES01043.1.

Moran K., Backman J., Brinkhuis H., Clemens S.C., Cronin T., Dickens G.R., Eynaud F., Gattacceca J., Jakobsson M., Jordan R.W., Kaminski M., King J., Koc N., Krylov A., Martinez N., Matthiessen J., McInroy D., Moore T.C., Onodera J., O’Regan M., Pälike H., Rea B., Rio D., Sakamoto T., Smith D.C., Stein R., St. John K., Suto I., Suzuki N., Takahashi K., Watanabe M., Yamamoto M., Farrell J., Frank M., Kubik P., Jokat W., Kristoffersen Y., 2006. The Cenozoic palaeoenvironment of the Arctic Ocean. Nature 441 (7093), 601-605. https://doi.org/10.1038/nature04800.

Morozov A.F., Petrov O.V., Shokalsky S.P., Kashubin S.N., Kremenetsky A.A., Shkatov M.Yu., Kaminsky V.D., Gusev E.A., Grikurov G.E., Rekant P.V., Shevchenko S.S., Sergeev S.A., Shatov V.V., 2013. New geological data substantiating continental nature of region of Central-Arctic rises. Regional'naya Geologiya i Metallogeniya (53), 34-55 (in Russian) [Морозов А.Ф., Петров О.В., Шокальский С.П., Кашубин С.Н., Кременецкий А.А., Шкатов М.Ю., Каминский В.Д., Гусев Е.А., Грикуров Г.Э., Рекант П.В., Шевченко С.С., Сергеев С.А., Шатов В.В. Новые геологические данные, обосновывающие континентальную природу области Центрально-Арктических поднятий // Региональная геология и металлогения. 2013. № 53. С. 34-55].

Mosher D.C., Shimeld J., Hutchinson D., Chian D., Lebedova-Ivanova N., Jackson R., 2012. Canada Basin revealed. In: Offshore Technology Conference, OTC-23797-MS, 11 p. https://doi.org/10.4043/23797-MS.

Nikishin A.M., Malyshev N.A., Petrov E.I., 2014. Geological Structure and History of the Arctic Ocean. EAGE Publications bv, Houten, The Netherlands, $88 \mathrm{p}$.

O'Sullivan P.B., Murphy J.M., Blythe A.E., 1997. Late Mesozoic and Cenozoic thermotectonic evolution of the central Brooks Range and adjacent North Slope foreland basin, Alaska: Including fission track results from the TransAlaska Crustal Transect (TACT). Journal of Geophysical Research 102 (B9), 20821-20845. https://doi.org/ 10.1029/96JB03411.

Parfenov L.M., Kuzmin M.I. (Eds.), 2001. Tectonics, Geodynamics and Metallogeny of the Territory of the Sakha Republic (Yakutia). MAIK Nauka/Interperiodika, Moscow, 571 p. (in Russian) [Тектоника, геодинамика и металлогения территории Республики Саха (Якутия) / Ред. Л.М. Парфенов, М.И. Кузьмин. М.: Наука/Интерпериодика, 2001. 571 c.].

Pease V., Drachev S., Stephenson R., Zhang X., 2014. Arctic lithosphere - A review. Tectonophysics 628, 1-25. https:// doi.org/10.1016/j.tecto.2014.05.033.

Petrov O., Morozov A., Shokalsky S., Kashubin S., Artemieva I.M., Sobolev N., Petrov E., Ernst R.E., Sergeev S., Smelror M., 2016. Crustal structure and tectonic model of the Arctic region. Earth-Science Reviews 154, 29-71. https://doi.org/ 10.1016/j.earscirev.2015.11.013.

Petrovskaya N.A., Savishkina M.A., 2014. Sedimentary cover of the Eastern Arctic Shelf - comparison of seismic complexes and main unconformity. Neftegazovaya geologiya. Teoriya i praktika 9 (3), Article 39 (in Russian) [Петровская Н.A., Савишкина М.А. Сопоставление сейсмокомплексов и основных несогласий в осадочном чехле шельфа Восточной Арктики // Нефтегазовая геология. Теория и практика. 2014. Т. 9. № 3. Статья 39]. https://doi.org/10.17353/2070-5379/39_2014.

Poselov V.A., Avetisov P., Butsenko V.V., Zholondz S.M., Pavlov S.P., 2012. The Lomonosov Ridge as a natural extension of the Eurasian continental margin into the Arctic Basin. Russian Geology and Geophysics 53 (12), 1276-1290. https://doi.org/10.1016/j.rgg.2012.10.002.

Rekant P.V., Gusev E.A., 2012. Seismic geologic structure model for the sedimentary cover of the Laptev Sea part of the Lomonosov Ridge and adjacent parts of the Amundsen Plain and Podvodnikov Basin. Russian Geology and Geophysics 53 (11), 1150-1162. https://doi.org/10.1016/j.rgg.2012.09.003.

Rekant P.V., Petrov O.V., Kashubin S.N., Rybalka A.V., Shokalsky S.P., Petrov E.O., Vinokurov I.Yu., Gusev E.A., 2015. History of formation of the sedimentary cover of Arctic basin. Multychannel seismic approach. Regional'naya Geologiya $i$ Metallogeniya (64), 11-27 (in Russian) [Рекант П.В., Петров О.В., Кашубин С.Н., Рыбалка А.В., Винокуров И.Ю., Гусев E.A. История формирования осадочного чехла глубоководной части арктического бассейна по данным сейсмических исследований МОВОГТ // Региональная геология и металлогения. 2015. № 64 C. 11-27].

Saltus R.W., Miller E.L., Gaina C., Brown P.J., 2011. Regional magnetic domains of the Circum-Arctic: a framework for geodynamic interpretation. In: A.M. Spencer, A.F. Embry, D.L. Gautier, A.V. Stoupakova, K. Sørensen (Eds.), Arctic Petroleum Geology. Geological Society, London, Memoirs, vol. 35, p. 49-60. https://doi.org/10.1144/M35.4.

Schmidt-Aursch M., Jokat W., 2016. 3D gravity modelling reveals off-axis crustal thickness variations along the western Gakkel Ridge (Arctic Ocean). Tectonophysics 691 (Part A), 85-97. https://doi.org/10.1016/j.tecto.2016.03.021.

Sekretov S.B., 2001. Northwestern margin of the East Siberian Sea, Russian Arctic: seismic stratigraphy, structure of the sedimentary cover and some remarks on the tectonic history. Tectonophysics 339 (3-4), 353-371. https:// doi.org/10.1016/S0040-1951(01)00108-1.

Sherwood K.W., Johnson P.P., Craig J.D., Zerwick S.A., Lothamer R.T., Thurston D.K., Hurlbert S.B., 2002. Structure and stratigraphy of the Hanna Trough, U.S. Chukchi Shelf, Alaska. In: E.L. Miller, A. Grantz, S.L. Klemperer (Eds.) Tectonic evolution of the Bering shelf - Chukchi Sea - Arctic Margin and Adjacent Landmasses. Geological Society of America Special Papers, vol. 360, p. 39-66. https://doi.org/10.1130/0-8137-2360-4.39. 
Shimeld J.W., Chian D., Jackson H.R., Hutchinson D., Mosher D.C., Wade J.A., Chapman C.B., 2011. Evidence for an important tectonostratigraphic seismic marker across Canada Basin and southern Alpha Ridge of the Arctic Ocean. Geological Survey of Canada, Open File 6822. https://doi.org/10.4095/289234.

Sokolov S.D., Bondarenko G.Ye., Morozov O.L., Shekhovtsov V.A., Glotov S.P., Ganelin A.V., Kravchenko-Berezhnoy I.R., 2002. South-Anyui suture, northeast Arctic Russia: Facts and problems. In: E.L. Miller, A. Grantz, S.L. Klemperer (Eds.), Tectonic evolution of the Bering shelf - Chukchi Sea - Arctic Margin and Adjacent Landmasses. Geological Society of America Special Papers, vol. 360, p. 209-224. https://doi.org/10.1130/0-8137-2360-4.209.

Soloviev A.V., 2008. Investigation of the tectonic processes of the convergent setting of lithosphere plates: fission-track dating and structural analysis. Nauka, Moscow, 319 p. (in Russian) [Соловьев А.В. Изучение тектонических процессов в областях конвергенции литосферных плит: методы трекового датирования и структурного анализа. М.: Наука, 2008. 319 с.].

Vernikovsky V.A., Dobretsov N.L., Metelkin D.V., Matushkin N.Yu., Koulakov I.Yu., 2013. Concerning tectonics and the tectonic evolution of the Arctic. Russian Geology and Geophysics 54 (8), 838-858. https://doi.org/10.1016/ j.rgg.2013.07.006.

Vernikovsky V.A., Morozov A.F., Petrov O.V., Travin A.V., Kashubin S.N., Shokal'sky S.P., Shevchenko S.S., Petrov E.O., 2014. New data on the age of dolerites and basalts of Mendeleev rise (Arctic Ocean). Doklady Earth Sciences 454 (2), 97-101. https://doi.org/10.1134/S1028334X1402007X.

Verzhbitsky V.E., Sokolov S.D., Tuchkova M.I., 2015. Present-day structure and stages of tectonic evolution of Wrangel Island, Russian Eastern Arctic Region. Geotectonics 49 (3), 165-192. https://doi.org/10.1134/S00168521150 3005X.

Verzhbitsky V.E., Sokolov S.D., Tuchkova M.I., Frantzen E.M., Little A., Lobkovsky L.I., 2012. The South Chukchi sedimentary basin (Chukchi Sea, Russian Arctic): age, structural pattern, and hydrocarbon potential. In: D. Gao (Ed.), Tectonics and sedimentation: Implications for petroleum systems. AAPG Memoir 100, p. 267-290. https://doi. org/10.1306/13351557M1003534.

Weigelt E., Franke D., Jokat W., 2014. Seismostratigraphy of the Siberian Sector of the Arctic Ocean and adjacent Laptev Sea Shelf. Journal of Geophysical Research: Solid Earth 119 (7), 5275-5289. https://doi.org/10.1002/2013JB 010727.

Zavarzina G.A., Shkarubo S.I., 2012. Tectonics of the western part of the Laptev sea shelf. Neftegazovaya Geologiya. Teoriya i Praktika 7 (3), Article 39 (in Russian) [Заварзина Г.А., Шкарубо С.И. Тектоника западной части шельфа моря Лаптевых // Нефтегазовая геология. Теория и практика. 2012. т. 7. № 3. Статья № 39]. Available from: http://www.ngtp.ru/rub/4/39_2012.pdf.

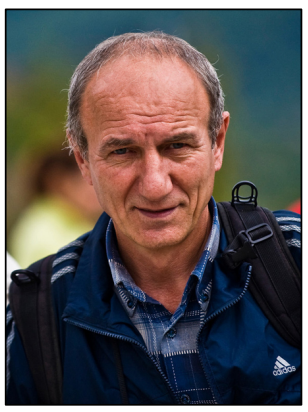

Nikishin, Anatoly M., Doctor of Geology and Mineralogy, Professor

M.V. Lomonosov Moscow State University, Faculty of geology

1 Leninskie Gory, Moscow 119991, Russia

Tel.: (495) 9394931; \ e-mail: nikishin@geol.msu.ru; amnikishin@gmail.com

Никишин Анатолий Михайлович, докт. геол.-мин. наук, профессор

Московский государственный университет им. М.В. Ломоносова, геологический факультет 119991, Москва, Ленинские Горы, 1, Россия

Тел.: (495) 9394931; $ه$ e-mail: nikishin@geol.msu.ru; amnikishin@gmail.com

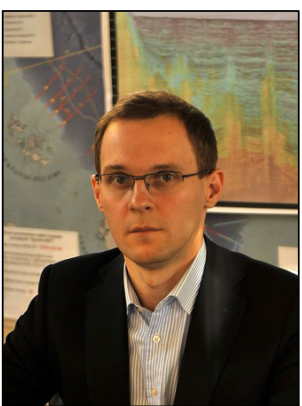

Petrov, Eugene I., Candidate of Geology and Mineralogy

Federal Subsoil Resources Management Agency (ROSNEDRA), Moscow, Russia

e-mail: epetrov@rosnedra.gov.ru

Петров Евгений Игнатьевич, канд. геол.-мин. наук

Федеральное агентство по недропользованию (РОСНЕДРА), Москва, Россия

e-mail: petrov@rge-geo.com 

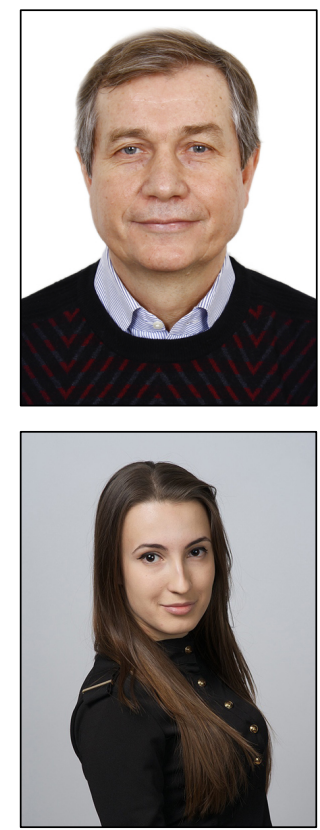

Malyshev, Nikolay A., Doctor of Geology and Mineralogy, Professor

Rosneft, Moscow, Russia

e-mail: n_malyshev@rosneft.ru

Малышев Николай Александрович, докт. геол.-мин. наук, профессор

Роснефть, Москва, Россия

e-mail: n_malyshev@rosneft.ru

Ershova, Vera P., Master of Geology and Mineralogy

M.V. Lomonosov Moscow State University, Faculty of geology

1 Leninskie Gory, Moscow 119991, Russia

e-mail: ershovavera@mail.ru

\section{Ершова Вера Павловна, магистрант}

Московский государственный университет им. М.В. Ломоносова, геологический факультет 119991, Москва, Ленинские Горы, 1, Россия

e-mail: ershovavera@mail.ru 